\title{
PROPAGAÇÃO DE FRUTÍFERAS EXÓTICAS POR ENRAIZAMENTO DE ESTACAS
}

\author{
BIANCA MOSCHETTA DE MORAES SARMENTO \\ Engenheira Agrônoma
}

Orientador: Prof. Dr. JOÃO ALEXIO SACARPARE FILHO

Dissertação apresentada à Escola Superior de Agricultura "Luiz de Queiroz", Universidade de São Paulo, para obtenção do título de Mestre em Agronomia, Área de Concentração: Fitotecnia.

P I R A C I C A B A

Estado de São Paulo - Brasil

Janeiro - 2004 
Dados Internacionais de Catalogação na Publicação (CIP) DIVISÃO DE BIBLIOTECA E DOCUMENTAÇÃO - ESALQ/USP

Sarmento, Bianca Moschetta de Moraes

Propagação de frutiferas exóticas por enraizamento de estacas / Bianca Moschetta de Moraes Sarmento. - - Piracicaba, 2003.

81 p. : il.

Dissertação (mestrado) - Escola Superior de Agricultura Luiz de Queiroz, 2003.

Bibliografia.

1. Anatomia vegetal 2. Brotação 3. Enraizamento de estaca 4. Estacas (Plantas) 5. Fisiologia vegetal 6 . Frutas tropicais 7. Propagação vegetal 8 . Regulador de crescimento vegetal I. Titulo

CDD 634

Permitia a copla total ou parcial deste documento, desde que citada a fonte - O autor" 
Aos meus pais Fernando (in memorian) e Miriam, aos meus irmãos Ana Corina, Fernandinho e Maria Carolina e à vovó Lady pelo amor, carinho, apoio, educação, confiança e estímulos constantes em todos os momentos da minha vida 


\section{AGRADECIMENTOS}

Agradeço a Deus pela oportunidade;

Aos meus amados pais, irmãos e vovó Lady;

À ESALQ, IAC e FAPESP por todo o apoio e condições oferecidas para a realização deste experimento;

Aos queridos mestres e amigos Prof. Dr. Celso Valdevino Pommer e Prof. Dr. João Alexio Scarpare Filho pela amizade, orientação, paciência, apoio, compreensão e valiosos ensinamentos que certamente contribuíram para que eu me tornasse uma pessoa melhor;

Aos colegas Dra. Laura Maria M. Meletti, Dr. Wellington Bastos e Dr. Paulo Gallo Boller, pela atenção, pelos ensinamentos e amizade demonstrados;

Aos meus queridos amigos Cristiane T. Barillari, Daniel de Castro Martins, Ana Maria de Meira e Sandra Bibiana A. Alzate por me apoiarem com tanto amor, carinho e paciência mesmo nos momentos mais difíceis desta jornada;

A todos os funcionários da ESALQ e do IAC que direta ou indiretamente contribuíram para a realização deste trabalho.

Que Deus abençoe a todos! 


\section{SUMÁRIO}

Página

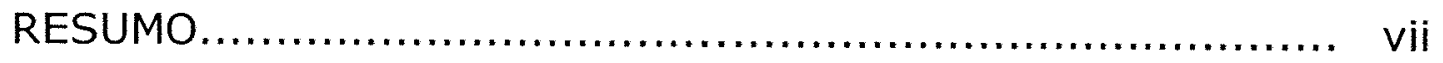

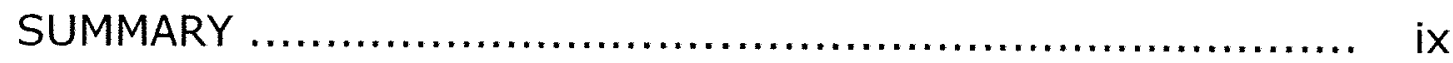

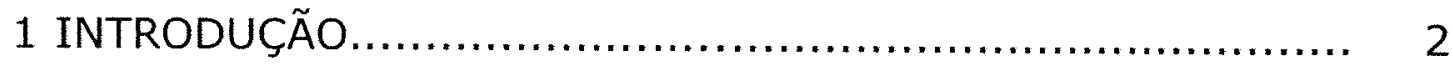

2 REVISÃO DE LITERATURA....................................... 3

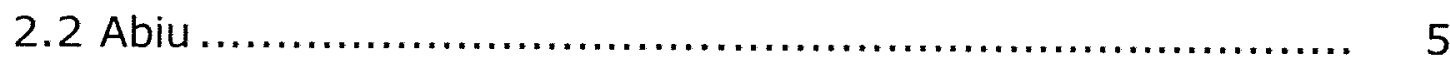

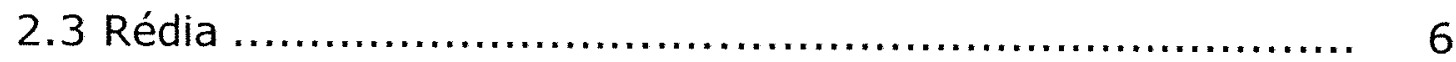

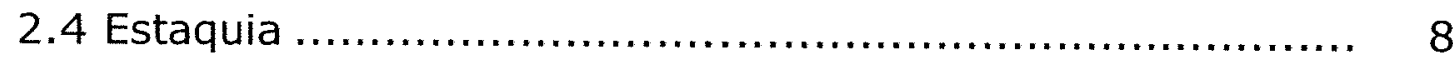

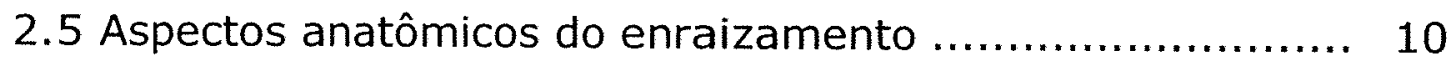

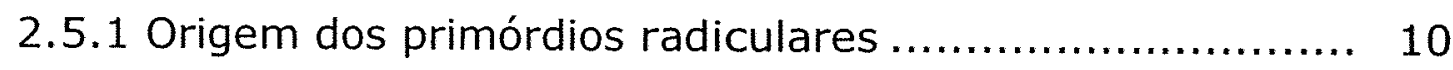

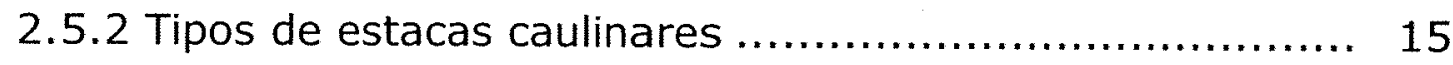

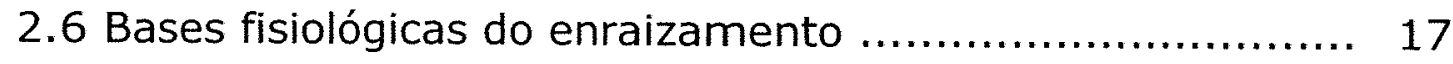

2.6.1 Hormônios vegetais....................................... 17

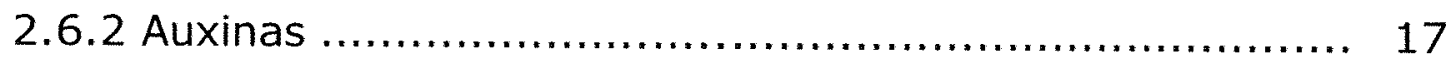

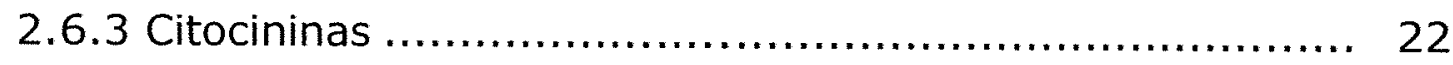

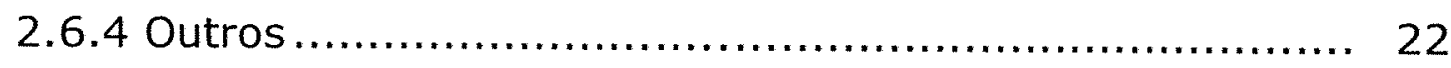

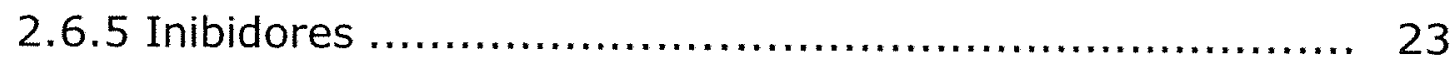

2.7 As bases moleculares da ação hormonal ...................... 24

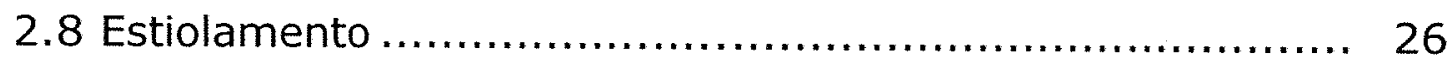

2.9 Fatores intrínsecos relacionados ao enraizamento de

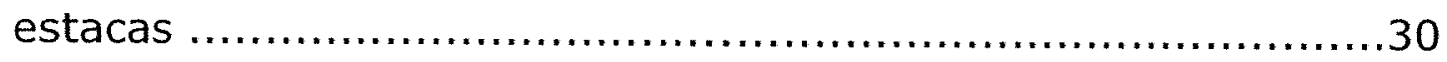

2.9.1 Influência do Boro no enraizamento ...................... 32 
2.9.2 Influência de carboidratos e outras substâncias sobre o enraizamento

2.10 Juvenilidade

2.11 Látex

3 MATERIAL E MÉTODOS

3.1 Experimentos 46

4 RESULTADOS E DISCUSSÃO 49

4.1 Experimento I 49

4.2 Experimento II 49

4.3 Experimentos "III A", "III B", "III a" e "III b". 51 5 CONCLUSÕES 57 REFERÊNCIAS BIBLIOGRÁFICAS 58 


\title{
PROPAGAÇÃO DE FRUTÍFERAS EXÓTICAS POR ENRAIZAMENTO DE ESTACAS
}

\author{
Autora: BIANCA MOSCHETTA DE MORAES SARMENTO \\ Orientador: PROF. DR. JOÃO ALEXIO SCARPARE FILHO
}

\section{RESUMO}

A fruticultura brasileira ocupa uma posição importante na produção frutícola mundial. O Brasil é um dos três maiores produtores mundiais de frutas, com uma produção que supera os 34 milhões de toneladas. Não obstante essa pujança da fruticultura comercial brasileira, várias espécies frutíferas, nativas e exóticas, apresentam potencial muito grande, ainda pouco explorado, principalmente aquelas espécies de clima subtropical e tropical. O objetivo deste projeto foi de realizar estudos sobre a viabilidade da propagação da Rédia e do Abiu por meio do enraizamento de estacas, a partir de árvores matrizes existentes na Estação Experimental do Instituto Agronômico de Campinas, em Mococa. Variáveis analisadas: número de brotações, número de estacas enraizadas, número de estacas sobreviventes, peso de raízes e número de folhas emitidas. A utilização de diferentes tipos de estacas e épocas de coleta não surtiram efeito, tampouco as técnicas tradicionalmente utilizadas como a aplicação de ácido indolbutírico e boro e o estiolamento e 
lixiviação testados no enraizamento de estacas. Diante dos resultados obtidos, verificou-se que nem o tipo de estaca, nem a aplicação de diferentes concentrações de reguladores vegetais com ação auxínica, assim como, a formulação da auxina utilizada, nem a época do ano influenciaram positivamente no enraizamento de estacas de Rédia e Abiu. 


\section{PROPAGATION OF EXOTIC FRUIT PLANTS ROOTING STEMS}

Author: BIANCA MOSCHETTA DE MORAES SARMENTO Adviser: PROF. DR. JOÃO ALEXIO SCARPARE FILHO

\section{SUMMARY}

Brazilian Fructiculture has an important standart on world's fruit production. Brazil is one of the three largest producers worldwide, with an up to 34 millions of ton production (Preços Agricolas, 2000; SECEX/ MDIC, 2002). In spite of that brazillian commercial fructiculture abundance, several fruit species, both native and exquisite, has shown a huge potential, yet few explored, mainly concerning to those subtropical and tropical climate species. This project has as a goal the study about viability of propagation of this two species through the stem rooting method, from matrix trees on "Estação Experimental do Instituto Agronômico de Campinas, in Mococa, in order to estimate the possibility of commercial exploration of those species. In front of the results, it was found that neither the kind of stem, nor the application of different doses of auxins, as well as the formulation of the auxin used, or even the season had influentied positively on stem rooting on Rédia and Abiu. 


\section{INTRODUÇÃO}

A fruticultura brasileira ocupa uma posição importante na produção frutícola mundial. O Brasil é um dos três maiores produtores mundiais de frutas, com uma produção que supera os 34 milhões de toneladas (Preços Agrícolas, 2000; SECEX/MDIC, 2002).

Não obstante esta pujança da fruticultura nacional sabe-se, no entanto, que temos um potencial muito grande de várias espécies frutíferas, nativas e exóticas, ainda pouco exploradas, principalmente aquelas espécies de clima subtropical e tropical.

Espécies como a Rédia (Rheedia gardneriana) e o Abiu (Pouteria caimito), produzem frutos com características que indicam potencialidade para exploração comercial, desde que superadas dificuldades como a de sua propagação. Tais frutíferas, pela sua pequena importância econômica atual, são exploradas regionalmente e muitas vezes extrativamente; e por outro lado a expansão da fronteira agrícola assim como outros fatores do desenvolvimento, tais como construções de rodovias, hidroelétricas, cidades, etc, que são vitais para o nosso país, contribui para a perda do valioso germoplasma e até mesmo pode-se chegar à extinção de algumas espécies.

Torna-se, portanto, imperativa, uma política decisiva de resgate desse material, o qual é preciso coletar, estudar e conservar para as gerações futuras. Nesse contexto, é essencial a atuação dos órgãos governamentais, mas é também de fundamental importância, a 
participação da sociedade como um todo, principalmente aqueles segmentos voltados para a agricultura e especialmente à fruticultura.

O objetivo deste projeto foi de realizar estudos sobre a viabilidade da propagação dessas duas espécies por meio do enraizamento de estacas, a partir de árvores matrizes existentes na Estação Experimental do Instituto Agronômico de Campinas, em Mococa, para estimar a possibilidade de exploração comercial das espécies frutíferas em questão. 


\section{REVISÃO DE LITERATURA}

\subsection{A importância da fruticultura no cenário econômico}

A fruticultura brasileira ocupa posição de destaque no cenário mundial, sendo suas produções de banana, laranja e mamão as maiores do globo, com destaque ainda para manga, abacaxi, abacate e castanha de caju.

A base agrícola da cadeia produtiva das frutas abrange 2,2 milhões de hectares, gera 4 milhões de empregos diretos e um PIB agrícola de US\$ 11 bilhões. Este setor demanda mão-de-obra intensiva e qualificada, fixando o homem no campo de forma única, pois permite uma vida digna de uma família dentro de pequenas propriedades e também nos grandes projetos. É possível alcançar um faturamento bruto de $\mathrm{R} \$ 1.000$ a $\mathrm{R} \$ 20.000$ por hectare. Além disso, para cada 10.000 dólares investidos em fruticultura, geram-se 3 empregos diretos permanentes e dois empregos indiretos. Visto por outro ângulo, 2,2 milhões hectares com frutas no Brasil significam 5 milhões de empregos diretos, haja visto, que a capacidade de ocupação de mão de obra registra até 6 trabalhadores ha ${ }^{-1}$ (Preços Agrícolas, 2000; FAO, 2002;).

O consumo per capta de produtos frutícolas da população brasileira é de $57 \mathrm{~kg} \mathrm{ano}^{-1}$ é considerado baixo, se comparado ao dos 
espanhóis (120 kg ano ${ }^{-1}$ ), italianos $\left(114 \mathrm{~kg} \mathrm{ano}^{-1}\right)$ ou alemães (112 kg $\mathrm{ano}^{-1}$ ) (IBRAF, 2002; OMC, 2002; FAO, 2002).

É, também, reconhecido como um dos segmentos mais importantes na alavancagem das exportações do País. As exportações de frutas frescas, no ano de 1999, totalizaram US $\$ 170$ milhões, mostrando o extraordinário crescimento de $31,9 \%$, em relação ao ano anterior, apesar da forte pressão sobre os preços médios internacionais, que registraram queda de quase $8,5 \%$, totalizando US $\$ 214.590$ milhões durante o ano de 2001, ao exportar $580.137 \mathrm{t}$ (Preços Agrícolas, 2000; SECEX/MDIC, 2002; FMI, 2002).

A despeito do significativo crescimento da área de algumas frutíferas no Brasil, sabe-se que certas espécies carecem de importância econômica, atualmente, apesar do grande potencial de exploração, tanto para o mercado interno como para o externo (Bezerra et al., 1990).

De acordo com Alcazar (1983), um incremento contínuo na produção e qualidade dos alimentos passa pela proteção e utilização eficaz dos recursos fitogenéticos e isso exige sua coleta, conservação, avaliação, documentação e intercâmbio.

Há uma vasta coleção de espécies frutíferas silvestres brasileiras ainda não completamente domesticadas, segundo Veiga et al., (1997). Para a região amazônica, estima-se que existam cerca de 500 espécies com potencial de uso. Já para as regiões sul e sudeste, existem mais de 150 espécies frutíferas, tendo algumas delas grande importância em seus respectivos ambientes naturais, quer seja por servirem de fonte de alimentação para as populações locais ou como fonte de renda, sendo comercializadas in natura, na forma de doces, sucos ou polpa congelada. A comercialização da polpa congelada tem 
sido opção da pequena e média indústria, pois o produto encontra mercado muito mais seguro, mesmo em termos de pequenos estabelecimentos, além da flexibilidade no uso de diversos tipos e tamanhos de embalagem, fatores importantes no crescimento constante da indústria de purês congelados, doces e extratos das mais diversas frutas (Tocchini et al., 1985).

Espécies frutíferas silvestres brasileiras, algumas inexploradas comercialmente no Brasil, são levadas para outros países onde muitas vezes suas potencialidades são estudadas e exploradas, como é o caso da Feijoa, uma frutífera silvestre, nativa da América do Sul, encontrada também no Brasil, que foi levada aos Estados Unidos, Europa e Nova Zelândia, a qual, segundo Mattos (1997), constitui hoje uma frutífera importante na produção e comércio de frutas daqueles países, inclusive para exportação.

Diante desse quadro, percebe-se a necessidade de incremento nos estudos com frutíferas nativas e exóticas, por parte de instituições brasileiras, numa forma de contribuir para que materiais genéticos tão importantes, não sejam perdidos, nos quais se procura caracterizar e disponibilizar germoplasma aos agricultores.

Espécies como a Rédia (Rheedia gardneriana) e o Abiu (Pouteria caimito), produzem frutos com características que indicam potencialidade para exploração comercial, desde que superadas dificuldades como a de sua propagação adequada.

\subsection{Abiu}

Acredita-se que a origem do nome "Sapote" seja derivado do asteca "tzapotlque é dado a todas as "frutas doces e macias". O Abiu 
é conhecido desde as civilizações pré-colombianas nas Américas do Sul e Central (Nakasone \& Paull, 1998).

A família Sapotaceae abrange um grande número de frutos comestíveis de espécies e gêneros diferentes. É nativa de Yucatán, sul do México e países da América Central. Espalhou-se pelas Ilhas do Caribe, América do Sul e Flórida, chegando às Filipinas através dos espanhóis. É facilmente encontrada na Costa da Índia e Sri Lanka.

O abieiro é uma fruteira cultivada desde a antigüidade, para a extração de base para o feitio de goma de mascar, além dos frutos. Pouteria caimito (syn. Achras caimito Banth) é conhecido como "Abiu" no Brasil e EUA, como "Cauje" no Equador, "Caimo" na Colômbia.

Encontra-se distribuída Equador, Trinidad, Flórida, Austrália e Ilhas Canárias pelos trópicos, porém não é explorada comercialmente (Clement, 1989; Shaw et al.,1998).

O fruto do Abiu (Figura 1a), tem sabor adocicado, muito apreciado. É usado contra afeç̧ões pulmonares crônicas e a casca da planta é antidiarréica, antidisentérica e febrífuga, enquanto o óleo extraído das sementes é usado como emoliente nas lesões inflamatórias da pele. Todas as partes da árvore e principalmente o fruto verde contêm um látex que pode ser utilizado no preparo de chiclete. Fornece madeira compacta e pesada que pode ser empregada na confecção de instrumentos musicais (RUBBO, 1985).

\subsection{Rédia}

A Rédia pertence a grande família Guttiferae, esta com mais de 1350 espécies. 
Popenoe (1920) citado em Fruitlovers (2001) declarou que um dos membros desta família, o Mangostão (Garcinia mangostana L.), é uma das frutas mais saborosas do mundo. Na América do Sul outras espécies pertencentes a mesma família também apresentam sabor superior, demonstrando potencial de comercialização até maior que o do Mangostão, devido a sua adaptação superior aos diversos climas.

A Rédia (Figura 1b) é encontrada desde a região amazônica até o Rio Grande do Sul, principalmente na floresta pluvial.

Em Fruitlovers (2001), afirma-se que o sabor dos frutos de Rheedia sp. é sempre considerado excelente, independendo da região em que são produzidos.

Sua madeira é empregada para confecção de cabos de ferramentas, moirões, construção civil, esteios, etc. Guimarães et al., (1997) testaram em ratos um extrato de folhas de Rheedia gardneriana e constataram a presença de biflavonóides com efeitos analgésicos significativos em relação a dores causadas por inflamações.

Os frutos são comestíveis e muito saborosos. A árvore é um tanto ornamental e pode ser aproveitada para a arborização urbana (Lorenzi, 1992). 


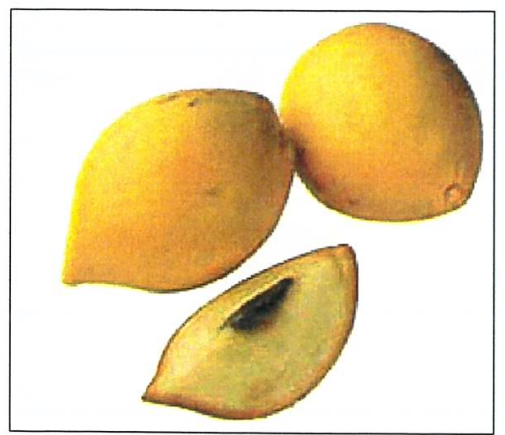

Fig. 1a : Frutos de Abiu

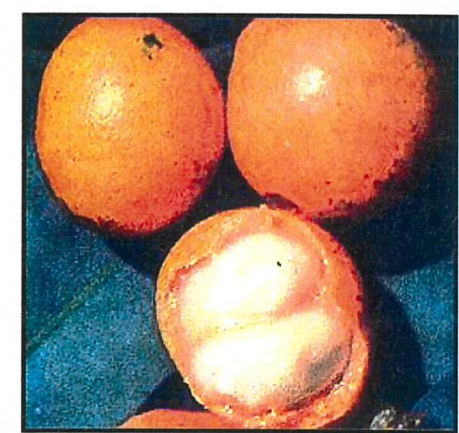

Fig. 1b: Frutos de Rédia

\subsection{Estaquia}

Scarpare Filho \& Almeida (2002) afirmam que propagação é a multiplicação de um indivíduo através de estruturas formadas no ciclo assexuado, ou seja, propágulos. Neste caso, é estabelecido o clone.

(Meletti et al., 2000) definem estaquia como sendo o processo de propagação assexual de plantas, baseado na capacidade de regeneração dos tecidos e emissão de raízes. Uma estaca (herbácea ou lenhosa), de ramo ou de raiz, deve conter no mínimo uma gema, e sendo destacada da planta-mãe, é colocada no solo para enraizamento.

A propagação vegetativa, principalmente através da estaquia, traz como principais vantagens, a obtenção de plantas uniformes, com a perpetuação dos caracteres agronômicos desejáveis e com redução da fase juvenil, além de ser uma técnica de fácil execução e de baixo custo, obtendo-se muitas plantas em curto espaço de tempo.

A propagação de plantas é a mais recomendada para frutíferas, porque possibilita a manutenção das boas características da planta que se deseja multiplicar (Simão, 1971; Lucchesi, 1995; Meletti et al., 2000). 
Por outro lado, é evidenciado por Grunberg (1928) como desvantagem das plantas obtidas por este método o desenvolvimento das raízes na maioria das vezes superficiais, com ausência da raiz pivotante, sendo facilmente arrancadas pela ação de ventos fortes. Diaz \& Santiago (1978), por sua vez, afirmam também que outra desvantagem é o fato de apresentar a possibilidade de difusão de patógenos.

Alguns autores, dentre eles Hartmann et al., (1975), Wright (1975) e Hartmann et al., (1981), afirmam que a propagação vegetativa é possível porque a divisão celular (mitose) ocorre durante a regeneração e o crescimento. A mitose mantém as características genéticas nas novas células produzidas, assim como 0 mesmo genótipo da planta original (Hartmann \& Kester, 1975).

Segundo Ono et al., (1996) é necessário realizar, primeiramente, um teste para a espécie ou cultivar que se queira propagar, permitindo, dessa forma, prever o tempo necessário para a formação das raízes, a necessidade ou não da aplicação de auxinas e sua concentração, o tipo adequado de substrato e o tipo de estaca, ou seja, lenhosa, semilenhosa ou herbácea. Tal procedimento é necessário, pois cada espécie ou cada cultivar responde diferentemente às diversas formas como é conduzida a propagação vegetativa, desde a colheita dos caules, produção das estacas, tratamento dessas e condições do local onde as estacas são cultivadas, até o momento da regeneração das raízes. Um procedimento ótimo para um cultivar pode não ser o ideal par o outro. 


\subsection{Aspectos anatômicos no enraizamento}

\subsubsection{Origem dos primórdios radiculares}

Os primórdios das raízes adventícias são provenientes de divisões de células do parênquima (células do callus ou de outros parênquimas). Antes de a raiz adventícia emergir, ela diferencia um promeristema, uma coifa, o início do cilindro vascular e o córtex. Por conseqüência da diferenciação dos elementos vasculares das raízes adventícias, células do callus ou de outros parênquimas, localizadas na parte proximal do primórdio diferenciam-se em elementos vasculares, proporcionando a conexão com os elementos correspondentes do órgão em formação (Esau, 1997; La Rue, 1952).

Janick (1966) afirma que a formação de raízes adventícias pode ser dividida em duas fases: a iniciação, que consiste na divisão celular e na diferenciação de algumas células em primórdios radiculares e em segunda fase, caracterizada pelo crescimento através da expansão resultante da combinação entre divisão e alongamento celular. Em contrapartida, Hartmann et al., (1990) dividem a formação de raízes adventícias em três etapas: a) desdiferenciação celular, necessária para a formação de raízes iniciais; normalmente estas se originam no floema secundário jovem, no câmbio ou na medula; b) diferenciação destes grupos de células em primórdios radiculares e c) crescimento e emergência das novas raízes, seguidos do estabelecimento de conexões vasculares entre a raiz e a estaca. A primeira fase depende fundamentalmente de fatores genéticos, sobre os quais influem auxinas e cofatores de enraizamento. As outras duas, de fatores 
nutricionais, entre eles, hidratos de carbono e componentes nitrogenados (Raven et al., 1992).

Costa Jr. (2000) relata que os primórdios radiculares estão geralmente associados à região nodal, embora possam aparecer em outras regiões, quando se utilizam estacas. Tal fato foi confirmado por Harbage et al., (1993), que ao avaliarem microestacas de maçã cv. Gala verificaram que apenas as células do parênquima do floema responderam à indução ao enraizamento através da formação de primórdios radiculares, apesar de as células do xilema, câmbio, córtex e medula terem demonstrado reação à aplicação de auxina, através do aumento da divisão celular.

De acordo com Raven et al., (1992) na maioria das plantas com sementes, as raízes se originam no periciclo. Em raízes de angiospermas as derivadas tanto do periciclo quanto da endoderme comumente contribuem com o novo primórdio de raiz, apesar de as derivadas da endoderme, em muitos casos, terem vida breve. Quando - primórdio de raiz aumenta em tamanho, ela se projeta para o córtex possivelmente secretando enzimas que digerem algumas células corticais localizadas no seu caminho. Enquanto estão ainda muito jovens, os primórdios de raiz desenvolvem coifa e meristema apical e aparecem os meristemas primários. Inicialmente, o cilindro vascular da raiz lateral e da raiz principal não estão conectados um ao outro. Os dois cilindros vasculares são conectados posteriormente, quando derivadas das células do parênquima intercalado se diferenciam em xilema e floema.

Quando as estacas são colocadas em condições favoráveis pode haver a formação de calo, uma massa irregular de células parenquimatosas em vários estágios de lignificação, oriundas da 
região vascular do câmbio e floema, podendo haver contribuição também do córtex e medula. Após a sua formação, as células podem se diferenciar em raízes (Rubbo, 1989).

De acordo com a proposta de Lovell \& Write (1986), as espécies vegetais podem ser divididas quanto à capacidade de enraizamento das estacas, em dois grupos: as de fácil e as de difícil enraizamento.

A capacidade das estacas caulinares de frutíferas, para formar raízes, parece estar relacionada com a estrutura anatômica do floema primário. O lenho das variedades de difícil enraizamento é freqüentemente caracterizado por apresentarem um alto grau de esclerificação. Em estacas retiradas de pereira, espécie considerada de difícil propagação por estaquia, observou-se que os raios do floema encontravam-se freqüentemente bloqueados com elementos lignificados pesados (Beakbane, 1961).

O esclerênquima (do grego skleros, duro + latim enchyma, infusão) é um tecido de sustentação composto por células de esclerênquima, incluindo as fibras e as esclereídes (células com a parede secundária lignificada e espessa).

Nos caules de monocotiledôneas, os feixes vasculares formam um sistema de cordões espalhados por todo o tecido fundamental.

Como nos feixes dos caules de dicotiledôneas, o floema se desenvolve a partir de células mais externas do cordão de procâmbio e o xilema, a partir das células mais internas. O feixe inteiro está envolvido por uma bainha de células de esclerênquima, com paredes espessas.

A Olea europaea é uma espécie de oliveira conhecida como sendo de difícil enraizamento. Ao estudarem-na, Fouad et al., (1990) 
observaram a presença de fendas no anel de esclerênquima, após cinco semanas do tratamento das estacas com auxina.

Sachs et al., (1964), entendendo que a simples presença de uma barreira física não podia ser capaz de impedir o enraizamento, demonstraram não haver relação entre densidade e continuidade de esclerênquima com facilidade de enraizamento em estacas de sete cultivares de oliveiras (Olea europea L.). Godin (1965), ratificou-os afirmando que plantas como Pfitosporum mesmo não tendo barreira de esclerênquima, dificilmente enraízam. Com isto, ele afirma que deve haver também um envolvimento químico.

Nas espécies de enraizamento difícil praticamente todas as raízes se originam do tecido cicatricial. Neste tecido as raízes surgem principalmente por divisões do câmbio e do parênquima liberiano ou de qualquer célula viva capaz de desdiferenciar (Lopes, 1995).

Fahn (1982) relacionou o fato de algumas estacas enraizarem facilmente devido à presença de raios vasculares largos, como em Vitis vinifera L. e Tamarix spp. Plantas com raios estreitos como Cerotonia, Pyrus e Carya sp. enraízam com dificuldade.

É óbvio que existe uma correlação entre o grau de esclerificação do floema primário e a capacidade de enraizamento de plantas que são difíceis de enraizar; assim, o uso de lenhos mais jovens, facilita a produção de raízes nas estacas. Esse método é explorado, pela propagação de estacas semilenhosas, em alta umidade. Essas estacas apresentam parede celular fina nas células do floema primário, sendo a lignificação geralmente ausente (Ono, 1990). Hartmann \& Kester (1975) sugerem que as diferenças bioquímicas nas células meristemáticas do ramo em vários estágios de desenvolvimento são mais importantes que as características anatômicas. 
Lucchesi (1995) afirma que existem fatores internos (genéticos) e externos (ambientais) influenciando o enraizamento de estacas de ramos.

Para pessegueiro (Prunus pérsica), Hanson (1978), com estacas lenhosas, semilenhosas e herbáceas tratadas com IBA obteve os melhores resultados com 3.700 ppm em estacas semilenhosas e herbáceas. Também Couvillon \& Erez (1980) obtiveram de 70 a $99,7 \%$ de estacas semilenhosas enraizadas de treze cultivares de pessegueiro, tratadas com IBA (1500, 2500 e 3500 ppm).

Inúmeros mecanismos podem contribuir para a falha na indução de raízes. Estacas lenhosas que não formam raízes podem apresentar alta atividade de enzimas que inativam a auxina por degradação oxidativa (Normanly, 1997) ou por conjugação (Cohen \& Bandurski, 1982). A recalcitrância em formar raízes também pode ser provocada pela presença de substâncias inibidoras da iniciação radicular (citocininas) e pela falta de resposta do tecido à auxina acumulada (Trewavas, 1981).

Sampaio \& Barbin (1983) recomendaram, para as espécies de difícil enraizamento, a utilização de estaquia herbácea sob condições de nebulização. A porção mais imatura de uma haste - a parte herbácea - há tempos, é reconhecida como o tipo de estaca de maior capacidade de enraizamento, porém constitui o material de propagação mais difícil de manter vivo (Adriance \& Brison, 1939; Hartmann \& Hansen, 1958; BROWSE, 1979). Williams et al.,(1984), observaram que o pobre enraizamento em muitas espécies lenhosas está mais correlacionado com a suberização do córtex, do que com a inibição através da esclerificação. 
Hartmann et al.,(1990) consolida tal suposição ao confirmar que algumas espécies continuam a ter problemas no enraizamento, mesmo que ocorra uma quebra na continuidade do anel esclerenquimático, por atividade meristemática.

\subsubsection{Tipos de estacas caulinares}

Os caules de muitas dicotiledôneas apresentam pouco ou nenhum crescimento secundário $e$, portanto são herbáceos e não lenhosos. Na maioria dos caules lenhosos, assim como na maioria das raízes lenhosas, a formação do súber usualmente ocorre em seguida ao início da formação do xilema e floema secundários, e os tecidos do súber substituem a epiderme como uma camada protetora nestas partes da planta. Súber, ou felema é formado para fora pelo câmbio da casca, ou felogênio, que pode formar também a feloderma para dentro. Juntos, estes três tecidos - súber, câmbio da casca e feloderma - formam a periderme (Ono, 1996).

Durante a diferenciação das células do súber, a superfície da parede interna é recoberta por lamelas de suberina, que consistem em camadas alternadas de suberina e cera, tornando o tecido altamente impermeável à água e gases. As paredes das células do súber podem também tornarem-se lignificadas. Na maturidade, as células do súber estão mortas (Hartmann et al., 1990).

De acordo com Ono et al., (1996), muitos autores concordam que as melhores estacas para o enraizamento são as semilenhosas.

Em uma planta, podem ser encontrados vários estádios entre a juvenilidade a maturidade. Nas plantas obtidas de sementes, geralmente a região basal é mais juvenil que a região terminal. 
Diferenças estas, que segundo Hartmann \& Kester (1975), se devem ao fato de que os meristemas existentes mais próximos da base formaram-se em épocas mais próximas à germinação que os das regiões terminais. Na propagação vegetativa, utilizam-se em geral, estacas retiradas de ramos juvenis, capazes de formar raízes rapidamente. Em geral, estacas com gemas caulinares formam raízes mais prontamente, provavelmente devido à maior produção de auxina Peres \& Kerbauy (2000).

Segundo Ono et al., (1996), outro fator, que afeta a resposta de enraizamento é o tamanho das estacas. Hartmann et al., (1990) afirmam que o tamanho das estacas varia de acordo com o tipo de lenho. Sendo assim, para estacas de ramos lenhosos arbustivos e de caules herbáceos, o comprimento pode variar de 7,5 a $12,5 \mathrm{~cm}$, enquanto que, o comprimento das estacas oriundas de ramos lenhosos arbóreos pode variar de 10 a $76 \mathrm{~cm}$.

As estacas de ramos terminais possuem altas concentrações de hormônios de crescimento, sendo este o motivo da manutenção de altos teores de carboidratos solúveis nas estacas durante o período de enraizamento (Thimba \& Itulya, 1982).

A presença de folhas nas estacas exerce influência estimuladora na formação de raízes. Os carboidratos que resultam da atividade fotossintética nas folhas contribuem para a formação destas raizes. 0 efeito estimulante das folhas e gemas se deve, contudo principalmente a produção de auxina. Estes órgãos são poderosos produtores de auxina e os efeitos são observados diretamente abaixo da folha ou gema, indicando que existe um transporte do ápice para a base (Hartmann \& Kester, 1983). Alta relação entre carbono e 
nitrogênio $(C / N)$ também favorece $a$ indução do enraizamento (Haissig, 1986).

\subsection{Bases fisiológicas do enraizamento}

\subsubsection{Hormônios vegetais}

A palavra hormônio vem do termo grego horman, que significa "excitar".

O hormônio vegetal é um composto orgânico que, em pequenas quantidades, promove, inibe ou modifica qualitativamente o crescimento e o desenvolvimento das plantas.

Algumas espécies de difícil enraizamento necessitam sofrer um tratamento na base da estaca, com tais substância para que haja a produção de raízes (Lucchesi, 1995).

Os principais hormônios vegetais atualmente utilizados na agricultura pertencem aos grupos das auxinas, giberelinas, inibidores e etileno (Castro, 1997).

\subsubsection{Auxinas}

As auxinas naturais recebem o nome de hormônios, enquanto que as sintéticas são chamadas simplesmente de reguladores de crescimento (Silva, 1994).

A auxina é uma substância promotora de crescimento, produzida nas gemas apicais e folhas novas e transportada até as raízes. Está envolvida na síntese de proteínas e promove o alongamento das células a certa distância do ápice. As auxinas podem 
ainda estimular a atividade cambial, promovendo a formação de calos nas estacas, sendo que tal atividade leva à formação de xilema e engrossamento das paredes celulares (Struckmeyer, 1951; Alvarenga e Carvalho, 1983).

O movimento das auxinas tanto em sistemas caulinares como em raízes é lento, em torno de $1 \mathrm{~cm}$ por hora. Seu transporte é polar, sempre em direção à base (bípeto) nos caules e folhas e em direção à extremidade (acrópeto) nas raízes (Raven et al., 1992). Devido ao transporte basípeto, as auxinas se acumulam na parte inferior das estacas, onde mais tarde raízes adventícias são formadas, mesmo naquelas plantadas em posição invertida Peres \& Kerbauy (2000).

A função da auxina está relacionada à divisão celular, estimulando a síntese ou desinibindo a ação de enzimas que atuam sobre as microfibrilas da parede celular, resultando em aumento da plasticidade da membrana. A nível genético, possivelmente a ação da auxina se dá como desrepressora de genes responsáveis pela síntese de enzimas envolvidas no processo de elongação e divisão celular (Weaver, 1976 e Antunes, 1995).

Potsch et al., (1972), citados por Ono, (1990), relatam que a ação das auxinas ocorre, inicialmente, a nível celular nos meristemas primário e secundário, estimulando a divisão celular e o subseqüente alongamento das células. Segundo Hartmann \& Kester (1983), essa ação inicial das auxinas culmina com a formação das raízes, que são resultantes das alterações morfogenéticas e da diferenciação das células das estacas. Além disso, estes hormônios levam ainda à síntese de RNA, o qual intervém da iniciação do primórdio radicular (Hess, 1969), favorecendo a atividade metabólica, necessária para o desenvolvimento dos novos tecidos da raiz, estimulando o 
crescimento destas (Altman, 1996; Breen \& Muraoca, (1973), citados por Ono, 1990).

O ácido indolbutírico (AIB), provavelmente é o melhor material para promover o enraizamento de grande número de espécies, por não ser tóxico em uma ampla faixa de concentração (Hartmann \& Kester, 1975). Sua molécula passa rapidamente nos diferentes tecidos da planta e os sistemas de enzimas destrutores de auxinas o destroem de forma relativamente lenta. É um produto químico persistente, de ação mais localizada e não tóxico Alvarenga et al., (1983).

As estacas tratadas com o AIB produzem raízes que rapidamente tornam-se longas e ramificadas, com o que acelera-se o transplante (Castro, 1997).

O AIB tem ação auxínica fraca, mas é relativamente estável translocando-se mais facilmente e é menos sensível aos sistemas enzimáticos de degradação das auxinas (Davis, 1987).

De acordo com Peres \& Kerbauy (2000), a grande superioridade do emprego do AIB com relação às outras auxinas no enraizamento de estacas é devido à não estimulação da produção de etileno, este que, atua como inibidor do elongamento celular.

Middleton et al., (1978) afirmam que o AIB é mais ativo que o IAA, por ser menos suscetível à inativação enzimática, explicando assim, a sua maior seletividade sobre a indução de raízes. De acordo com González \& Schimidt (1992), o IBA apresentou performance significativamente superior à do NAA em estudos realizados com estacas de goiabeira "Kumagai".

Lucchesi (1995) reforça a importância da concentração de auxina (do regulador vegetal) utilizada. Segundo esse autor, o teor 
endógeno de auxina da própria estaca, somado à quantidade aplicada na sua região basal, pode tornar-se inibitório, pois aumenta a concentração e o efeito (indução de primórdios radiculares). Sabe-se que a concentração ótima é mais baixa nas raízes, mais alta nos caules e intermediária nas gemas. Este nível varia de espécie para espécie.

Ainda segundo aquele mesmo autor, sistemas radicular tratado com auxinas pode produzir numerosas raízes laterais novas, mas que por causa da elevada concentração não conseguem alongar-se. As raízes alongar-se-ão, ao reduzir-se a concentração de auxina para valores inferiores ao nível inibidor.

Iritani (1981) sugere que estacas herbáceas devem ser tratadas com baixas concentrações de auxina, enquanto que, para estacas lenhosas e de difícil enraizamento, a concentração deve ser alta, próxima a fitotóxica.

Á luz das interações acima discutidas formula-se uma pergunta: existiria alguma combinação hormonal responsável por maior alongamento radicular? Segundo Peres \& Kerbauy (2000) a resposta é a manutenção de uma proporção ABA/AIA relativamente elevada e a concomitante inibição da acumulação do etileno.

Variações qualitativas e quantitativas da luz que incide sobre as plantas matrizes, podem favorecer a inibição de co-fatores para -o enraizamento, o aumento da atividade da peroxidase a síntese inadequada de IAA (ácido indolacético) e a formação de barreiras histológicas ao desenvolvimento das raízes adventícias (Hartmann et al., 1990). Esta hipótese foi comprovada por De Vier \& Geneve (1997) ao avaliarem estacas de crisântemo (cv. Boaldi) oriundas de plantas sob fotoperíodo indutivo ao florescimento (dias longos) e plantas sob 
fotoperíodo vegetativo (dias curtos). Eles concluíram que as porcentagens de enraizamento foram significativamente maiores nas estacas retiradas de matrizes sob dias curtos. Moe \& Andersen (1988) afirmam que o fotoperíodo que induz o florescimento aparentemente inibe o enraizamento das estacas.

É conveniente considerar que a eficácia dos produtos auxínicos é distinta para cada espécie e é influenciada tanto pela concentração quanto pelo veículo que se utiliza para aplicá-los. Ademais, existem dificuldades relativas à preparação dos produtos auxínicos, já que são pouco solúveis em água e os efeitos negativos que os solventes empregados para sua solubilização podem ocasionar às plantas. A forma de tratamento varia com o veículo utilizado, assim, para veículos sólidos, onde o produto fica aderido à base da estaca, o período de exposição é muito mais prolongado que para veículos líquidos, onde a base da estaca é imersa na solução por um determinado período. Como veículo sólido, o mais utilizado é o pó de talco, embora, segundo Avery \& Johnson (1947) e Oliveira (2001), também podem ser empregados sais de potássio de AIB solúveis em água e a farinha de soja, ou pó de carvão, aos quais é adicionado o regulador de crescimento. Como veículo líquido, é utilizada a água destilada, porém, como o AIB é pouco solúvel em água, necessita ser previamente diluído em álcool ou hidróxido (Hartmann \& Kester, 1983; Cuquel, 1992; Oliveira, 2001), após o que adiciona-se a água para atingir-se a concentração adequada.

Resultados contraditórios são apresentados pela literatura. Panelli et al., (1980), questionam a necessidade da aplicação de auxina na base das estacas, uma vez que bons resultados de 
enraizamento podem ser alcançados com a aplicação de AIB via foliar, duas vezes por semana.

\subsubsection{Citocininas}

As citocininas são quimicamente relacionadas a certos componentes dos ácidos nucléicos; são reguladores vegetais que participam ativamente dos processos de divisão e diferenciação celular, particularmente em cultura de tecidos (Awad e Castro, 1983).

As citocininas são estimuladoras da iniciação de gemas caulinares e inibidoras da formação de raízes, embora sua biossíntese seja predominantemente nesse último tipo de órgão (Davies, 1995).

Após biossíntese nas raízes, as citocininas entram no fluxo ascendente do xilema (Davies, 1995) e são transportadas para os sítios de iniciação de gemas nos caules.

Em cultura de medula de tabaco, uma alta concentração de auxina promove a formação de raízes, enquanto que uma alta concentração de citocininas estimula a formação de gemas. As citocininas são transportadas via xilema a partir das raízes para o sistema e têm como local de biossíntese o ápice radicular (Raven et al., 1992).

\subsubsection{Outros}

As giberelinas participam da regulação do crescimento de órgãos vegetais. Elas estão presentes em várias concentrações e em todas as partes das plantas, porém, as mais altas concentrações são encontradas nas sementes imaturas. 
As giberelinas têm efeitos marcantes no alongamento dos caules e folhas de plantas intactas, através do estímulo tanto da divisão, quanto do alongamento celular.

Embora as giberelinas sejam fitohormônios de essencial importância para a planta, agindo em conjunto com outros fitohormônios, estas substâncias apresentam a peculiaridade de inibirem o enraizamento (Rezende et al., 2001).

O transporte das giberelinas nas plantas é de natureza não polar, ocorrendo na maioria dos tecidos, incluindo floema e xilema.

O etileno também é um regulador natural do crescimento vegetal, induzindo respostas fisiológicas distintas, tais como a abscisão e o amadurecimento dos frutos. É biossintetizado em muitos tecidos em resposta ao estresse, especialmente naqueles submetidos a senescência ou amadurecimento. Por ser um gás, o etileno move-se por difusão do seu local de origem (Awad e Castro, 1983; Raven et al., 1992).

O etileno é o principal inibidor do crescimento radicular (Stenlid, 1982). Tanto as auxinas quanto as citocininas inibem o crescimento radicular devido ao seu efeito na produção de etileno (Bertell \& Eliasson, 1992; Cary et al., 1995). A constatação de que as auxinas estimulam a produção de etileno explica em parte o seu duplo papel promovendo a iniciação radicular e ao mesmo tempo inibindo o alongamento das raízes formadas Peres \& Kerbauy, 2000).

\subsubsection{Inibidores}

Os inibidores naturais promovem retardamento no crescimento do meristema apical. Este efeito retarda efetivamente o alongamento 
do caule e das raízes, inibindo ainda a germinação das raízes. Têm como local de biossíntese as folhas maduras, especialmente em resposta ao estresse hídrico. Pode ser sintetizado em sementes. É exportado a partir das folhas pelo floema (Awad e Castro, 1983; Raven et al., 1992).

Recentemente, foi descoberto que os triazóis como paclobutrazol e uniconazole, inibem a biossíntese de giberelina, por ligarem o nitrogênio do grupo triazol ao ferro da enzima citocromo P450, bloqueando o sítio de ligação da enzima (Cremlyn, 1991, citado por Rodrigues et al., 1998). Ao ser absorvido pelas folhas, o produto alcança os meristemas subapicais inibindo a síntese endógena da giberelina, causando supressão doalongamento celular e conseqüente redução do crescimento vegetativo (Oshio, 1988; Pereira, 1992).

\subsection{As bases moleculares da ação hormonal}

O desenvolvimento dos órgãos (morfogênese) pode ser descrito como uma série coordenada de divisões celulares com subseqüente alongamento. Existem evidências de que os cinco grupos de hormônios vegetais atuam na coordenação do crescimento e desenvolvimento operando como mensageiros químicos entre as células (quadro 1), baseiam-se em provas sobre a influência que exercem nas taxas de divisão celular, bem como na taxa de direção da expansão celular (Awad e Castro, 1983; Raven et al., 1992). 


\begin{tabular}{|c|c|c|c|c|}
\hline & $\begin{array}{l}\text { Taxa da } \\
\text { divisão } \\
\text { celular }\end{array}$ & $\begin{array}{l}\text { Taxa da } \\
\text { expansão } \\
\text { celular }\end{array}$ & $\begin{array}{l}\text { Direção da } \\
\text { expansão } \\
\text { celular }\end{array}$ & $\begin{array}{l}\text { Diferenciação } \\
\text { (Expressão } \\
\text { gênica) }\end{array}$ \\
\hline $\begin{array}{l}\text { Hormônio } \\
\text { Auxina } \\
\text { Citocinina } \\
\text { Etileno }\end{array}$ & $\begin{array}{l}\text { e.p } \\
\text { e.p. } \\
\text { e.p/e.n. }\end{array}$ & $\begin{array}{c}\text { e.p. } \\
* \\
\text { e.p/e.n. }\end{array}$ & $\Uparrow$ & $\begin{array}{l}\text { e.p. } \\
\text { e.p. } \\
\text { e.p. }\end{array}$ \\
\hline $\begin{array}{l}\text { ABA } \\
\text { Giberelinas }\end{array}$ & $\begin{array}{l}\text { e.n. } \\
\text { e.p. }\end{array}$ & $\begin{array}{l}\text { e.n. } \\
\text { e.p. }\end{array}$ & $\Uparrow$ & $\begin{array}{l}\text { e.p. } \\
\text { e.p. }\end{array}$ \\
\hline
\end{tabular}

"e.p": efeito positivo; "e.n": efeito negativo; "*": efeito pequeno ou nulo; " $\Uparrow$ ": expansão longitudinal; " $\Leftrightarrow$ ": expansão lateral. Raven et al., (1992).

Quadro 1- Influência dos hormônios em relação aos processos celulares básicos.

$O$ etileno e o ABA inibem o crescimento da planta e podem causar um decréscimo na extensibilidade da parede celular, enquanto que as auxinas e as giberelinas estimulam o crescimento vegetal, através do aumento da extensibilidade da mesma.

Levando se em conta as peculiaridades da síntese, transporte e ação das auxinas e citocininas, podemos entender o crescimento integrado entre caules e raízes do seguinte modo: um intenso crescimento do sistema radicular (em locais com boa disponibilidade de água e nutrientes), implicaria num aumento da produção e transporte de citocininas, estimulando a iniciação compensatória de gemas caulinares. Por outro lado, em locais com bom suprimento de O2, $\mathrm{CO} 2$ e luz, as novas gemas formadas garantiriam o suprimento de auxina necessária à iniciação de mais raízes (Peres \& Kerbauy, 2000). 


\subsection{Estiolamento}

O pré-tratamento de plantas matrizes na ausência de luz tem proporcionado excelentes resultados na propagação vegetativa de diversas espécies lenhosas, especialmente frutíferas como: abacateiro, goiabeira, mangueira, macieira entre outras (Biasi, 1996).

O estiolamento é uma técnica bastante interessante e pouco utilizada na propagação vegetativa por estaquia, apesar de conhecida há quase um século. Gardner (1936) obteve aumento de $70 \%$ no enraizamento de estacas de macieira caracterizadas como sendo de difícil propagação, ao cobrir com fita preta uma pequena extensão próxima ao ápice de brotações antes de coletar as estacas, mantendo-as nessa condição até o crescimento permitir a formação de uma estaca a partir da região estiolada.

Esta técnica, de acordo com Hartmann et al., (1981) e Salisbury \& Ross (1978), vem sendo utilizada com bastante sucesso em estacas de espécies de difícil enraizamento, citando entre as frutíferas o abacateiro, a mangueira, a macieira, a cerejeira entre outras.

Atualmente, algumas plantas de difícil enraizamento têm enraizado com a ajuda de um conjunto de técnicas modernas como o estiolamento total ou localizado e estrangulamento (Eliasson \& Brunes 1980; Lopes 1995; Nageswara Rao et al., 1988).

Não estão ainda bem definidos quais os efeitos prejudiciais da luz no enraizamento das estacas. Segundo Lopes (1995) tal fato pode ser atribuído a fotoinativação de hormônios ou a outros fatores naturais de enraizamento nos tecidos cortados da estaca. 
Ryan (1969) sugere que algum fator essencial ao enraizamento seja formado na presença da luz, mas é inibido se as estacas permanecerem expostas à luz.

Uma série de trabalhos evidenciam a influência da associação de substâncias de crescimento e estiolamento. Hartmann \& Kester (1975) afirmaram que somente o uso de reguladores de crescimento não tem feito sucesso em algumas espécies, porém, a associação com o estiolamento melhorou o enraizamento de estacas de abacateiro (Persea americana M.) da raça antilhana, assim como de outras espécies. O processo consiste no crescimento de toda a planta, ou parte dela, sob condições de ausência total ou parcial de luz Bassuk \& Maynard (1987). Segundo Bassuk et al., (1987), um forte sombreamento superior a $90 \%$ mostra-se suficiente. Nessa região capeada, não deve haver o efeito de foto-oxidação de material normalmente acumulado (fotossintetizados, hormônios e cofatores).

Existem três tipos de estiolamento: o estiolamento da base das estacas, também conhecido como estiolamento basal ou bandagem, estiolamento da planta inteira e estiolamento de ramos (Boliani, 1986; Hartmann et al., 1990).

A eficiência de enraizamento geralmente é maior combinando o estiolamento com o anelamento ou aplicação de auxinas, conforme já verificado para fruteiras como macieira, jaqueira e abacateiro (Biasi, 1996). A região anteriormente coberta dos ramos apresentará menor lignificação, aumento no teor de amido, ajustamento endógeno de hormônios e conseqüentemente, relativo facilidade na indução de primórdios radiculares (Bassuk et al., 1985; Lucchesi, 1995). Bassuk \& Maynard (1987) afirmam que o estiolamento facilita o enraizamento 
nas brotações estioladas, pois diminui as propriedades mecânicas dos tecidos.

A falta de clorofila que caracteriza o estiolamento, aparentemente não influencia no enraizamento e que geralmente o reverdecimento ocorre rapidamente. Os ramos estiolados apresentam diferenças anatômicas que podem favorecer $\circ$ aparecimento de primórdios radiculares. A formação de tecidos mais tenros, com menor resistência mecânica, se deve a menor suberização dos tecidos externos (Maynard \& Bassuk, 1988). Esta prática também aumenta a sensibilidade dos ramos à auxina, e tem sido relacionada às mudanças em compostos fenólicos que atuam como inibidores da IAA oxidase (Hartmann et al., 1990).

Jackson (1986) sugere que para inúmeras espécies, a capacidade de enraizamento das estacas, aumenta com o desenvolvimento das plantas matrizes situadas em condições de baixa intensidade luminosa. Teoricamente, segundo ele, a redução da intensidade luminosa aumenta o enraizamento porque: a) o nível de inibidores de crescimento é maior em intensidades luminosas altas; b) o nível de auxinas em plantas crescendo a alta intensidade luminosa, embora seja maior, concentra-se nos pontos de crescimento, com as partes basais apresentando baixos níveis; c) deve haver um nivel ótimo de carboidratos para a auxina promover o enraizamento, acima do qual, o processo é comprometido, como em plantas crescidas em alta intensidade luminosa e d) a resposta a irradiância, parece ser variável e relacionada a diferenças genéticas.

Medrado (1992) observou que em seringueira, o estiolamento total aumentou as concentrações de $\mathrm{N}, \mathrm{K}$ e $\mathrm{Mg}$ e diminui as de $\mathrm{Ca}$ e a de $P$, neste caso, em estacas que foram submetidas a 
estrangulamento. O estiolamento localizado aumentou a concentração de $\mathrm{N}, \mathrm{P}$ e $\mathrm{Mg}$ em estacas submetidas ao estiolamento e diminuiu a de P em estacas não estranguladas, não obtendo, contudo sucesso no enraizamento.

Biasi (1996), atesta que a inibição da lignificação pelas auxinas serve como um mecanismo de indução a alongação. Os compostos precursores da lignina são polimerizados por peroxidases ou outros sistemas fenólicos oxidantes. A auxina tem efeito sobre a atividade $\mathrm{e}$ níveis de peroxidase, afetando assim, a formação da lignina, já que a mesma, depende de peroxidações.

Heller et al., (1994) constataram que o sombreamento moderado das plantas matrizes, da ordem de 50\%, proporcionou $90 \%$ de enraizamento de estacas da ornamental Coleonema aspalathoides, enquanto que estacas oriundas de matrizes em condições normais de luminosidade apresentaram $30 \%$ de enraizamento. Os autores concluíram que porcentagens mais elevadas de sombreamento, 75 e $87,5 \%$, apresentaram resultados inferiores devido a menor quantidade de carboidratos nas estacas proporcionada pela diminuição na atividade fotossintética.

Em trabalhos realizados por outros autores, como Frolich (1951) com abacateiro; Singh \& Taotia (1961) com mangueira; Kawase (1965) com várias espécies e Frolich (1972) com abacateiro, foram obtidos resultados semelhantes, mostrando sempre que a associação de técnicas de enraizamento (regulador de crescimento, estiolamento, processos mecânicos, etc.), surtem mais efeitos do que se utilizadas isoladamente.

Mohamed \& Sorhaindo (1984), em trabalhos com estacas de abacateiro, cultivares Pollock e o híbrido Lula, verificaram que o uso 
do estiolamento, associado ao AIB, proporcionou melhor enraizamento em comparação à testemunha. Maynard \& Bassuk (1990) confirmaram que estacas semilenhosas estioladas de Acer griseum enraizaram melhor $(41 \%)$ se comparadas às testemunhas $(10 \%)$ e que o estiolamento basal não aumentou satisfatoriamente a porcentagem de enraizamento (18\%).

Para Hansen \& Potter (1997), nem sempre os resultados obtidos com estiolamento são satisfatórios, pois a resposta a tais tratamentos pode diferir entre espécies ou até mesmo entre cultivares.

Para as espécies que ainda não foram estudadas, recomenda-se testar inicialmente o estiolamento localizado com posterior estaquia, já que constitui no procedimento de mais fácil execução. Mas, se a resposta da espécie não for satisfatória, pode-se combinar o estiolamento com o anelamento dos ramos ou aplicação exógena de reguladores de crescimento ou então, usar a técnica do estiolamento total (Biasi, 1996).

\subsection{Fatores intrínsecos relacionados com o enraizamento de estacas}

A propagação de plantas por meio de estacas caulinares é um processo empregado em muitas espécies frutíferas, porém os resultados são variáveis de acordo com grande número de fatores como: potencial genético, condição fisiológica e nutricional da planta matriz, idade da planta, época de coleta e tipo de estacas, concentração de regulador de crescimento aplicada, fatores externos e ambientais, condições nas quais as estacas estão sujeitas até o enraizamento, como temperatura, luz, umidade, entre outros 
(Hartmann \& Kester, 1990; Fachinello et al.,1995; Scarpare Filho et al., 1999; Vilanova, 1959; Montero et al., 1985). Em adição, Lucchesi, (1995) reforça a grande importância exercida por alguns fatores do meio em uma propagação vegetativa racional. Assim, são fatores decisivos nesse empreendimento a temperatura do ar e do solo, a radiação solar (intensidade e determinadas faixas do espectro da luz solar) e a nutrição mineral da planta matriz de onde serão retiradas as estacas no processo da propagação.

Ono et al., (1996) citam vários aspectos que devem ser observados para se obter sucesso na reprodução vegetal através de estacas caulinares, ou seja, coletar os ramos nas primeiras horas do dia e conservá-los, em sacos de polietileno pulverizados com água, em local sombreado e arejado, até o momento da confecção das estacas; realizar tratamento auxínico, quando necessário, de acordo com o tipo de estaca, levando em consideração a concentração e o tempo de aplicação do fitorregulador, e cultivar as estacas em local adequado, com alta umidade e temperatura entre 15 e $25^{\circ} \mathrm{C}$.

O estado nutricional da planta matriz é um fator importante a ser considerado no momento de escolha das estacas. Quanto à adubação nitrogenada da planta matriz, sabe-se que níveis baixos e médios de $\mathrm{N}$ implicam em maiores índices de enraizamento (Hartmann et al., 1990).

Grande importância tem ainda os micronutrientes nas dosagens corretas. O manganês é ativador da IAA oxidase, que destrói a auxina endógena das estacas, prejudicando o enraizamento.

O zinco faz parte de várias enzimas e está também envolvido na síntese de proteínas e do triptofano (precursor da auxina) por isso, as aplicações desse elemento aumentam os teores de auxina endógena 
nos ramos e conseqüentemente das estacas. O zinco não é requerido somente para síntese de auxina, mas para a manutenção de um estado ativo. A falta de zinco acarreta excessiva destruição de auxina, provavelmente por oxidação. (Blazich, 1988a; Kersten, 1990). A aplicação de 5 e 10 ppm de zinco, aumentou a concentração de triptofano em grãos de arroz (Singh, 1981).

\subsubsection{Influência do Boro no enraizamento}

Quanto ao Boro, tem-se observado que na sua deficiência aparecem vários distúrbios prejudiciais ao desenvolvimento dos tecidos meristemáticos, como morte dos ápices das raízes e tecidos do câmbio (Mengel \& Kirby, 1979).

As funções do boro estão relacionadas com as do cálcio, ou seja, regulação do funcionamento da membrana e da parede celular, divisão e aumento das células, bem como favorecimento da germinação do grão de pólen, além de estar presente no processo de formação de hormônios. Apesar de não ser um constituinte enzimático, explicam-se os efeitos sobre as reações do tipo oxidativo como catalase, polifenol oxidase, peroxidase, pela ativação da síntese de clorofila e a produção de açúcar. Participa ainda, no transporte de glucídios, enquanto se completa com este, atravessando com mais facilidade a membrana celular. Intervém no metabolismo do nitrogênio, nos mecanismos de ação da giberelina e na síntese do ácido b-indolacético (auxina) e também no seu transporte (Terra, 2001).

Brenchley \& Warington (1927) citados por Leonel \& Rodrigues, (1993b) foram os primeiros pesquisadores a comprovar a influência 
do elemento boro no desenvolvimento e crescimento das raízes adventícias.

Murray et al., (1957); Weiser \& Blaney, (1967) afirmam que o boro influencia no enraizamento de estacas, interagindo sinergicamente com o IBA, aumentando o sucesso da formação de raízes.

Segundo Gauch \& Dugger (1953), as folhas de plantas deficientes em B apresentam, comparativamente, maiores concentrações de açúcares, contudo a concentração nos ramos é baixa, indicando que o teor de $B$ influencia a translocação dos fotossintatos. Portanto, o boro reage com os açúcares formando um complexo ionizável: o açúcar-borato, que atravessa com mais facilidade a membrana celular, que o borato. Os autores caracterizam a deficiência de boro, como a ausência de açúcares no câmbio, e que a falta deste nutriente, acarreta a concentração de carboidratos no local de síntese.

Tal fato foi comprovado por Kersten (1990) ao avaliar o enraizamento de estacas de ameixeira (Prunus salicina) cv. Carmesin e Grancuore, coletadas em quatro épocas (maio, novembro, dezembro e fevereiro), em relação à aplicação de $B$ às plantas matrizes. No cultivar Carmesin, houve diferença significativa apenas naquelas coletadas em dezembro, onde as plantas não tratadas com B produziram estacas que tiveram porcentual de enraizamento superior aquelas tratadas, ou seja, foi comprovado o efeito positivo do B no comprimento das raízes primárias e, ainda, na produção de matéria seca.

Ferreira et al., (2000), trabalhando com Pau-leite (Sapium glandulatum Pax) concluíram que o tratamento que melhor promoveu 
o enraizamento das estacas foi IBA $4000 \mathrm{mg} \cdot \mathrm{L}-1$, + $150 \mathrm{mg} \cdot \mathrm{L}-1 \mathrm{em}$ solução, apresentando $28 \%$ de enraizamento.

Leonel \& Rodrigues (1993a), estudaram as interações entre os ácidos indol-butírico, alfa-naftaleno-acético e bórico no desenvolvimento de raízes em estacas de porta-enxertos de videira (Vitis vinifera L.). A pesquisa demonstrou que o IBA $2.000 \mathrm{ppm}+$ H3BO3 150 mg.L-1 propiciou o enraizamento em 88,87\% das estacas, contudo não diferiu estatisticamente da testemunha (H20 - 61,10\%).

Ainda no ano de 1993 (b), os mesmos autores avaliaram a eficiência do uso de IBA + ácido bórico em estacas de lichieira (Litchi chinensis). Este trabalho, porém, demonstrou que, dos tratamentos utilizados, nenhum foi efetivo na formação de raízes, havendo somente a formação de calos.

Jarvis et al., (1984), detectaram maior desenvolvimento das raízes em estacas de P.aureus, favorecido pelo aumento da concentração de IBA, principalmente quando essas estacas eram tratadas com ácido bórico à $150 \mathrm{mg} \cdot \mathrm{L}^{-1}$, o que levou ao máximo de crescimento das raízes.

Em contrapartida, Linsingen et al., (2000) ao testarem Erythrina speciosa concluiu que a aplicação de IBA em solução foi mais eficaz na promoção do sistema radicial em estacas de Erythrina, do que a aplicação em talco, onde IBA $3000 \mathrm{mg} \cdot \mathrm{L}^{-1}$ e IBA $6000 \mathrm{mg} \cdot \mathrm{L}^{-1}$ promoveram o enraizamento de $58 \%$ das estacas. A adição de ácido bórico não potencializou o efeito da auxina, onde IBA $3000 \mathrm{mg} \cdot \mathrm{L}^{-1}+$ $150 \mathrm{mg} . \mathrm{L}^{-1}$ ácido bórico promoveu somente $24 \%$ de enraizamento.

Nicoloso et al., (1999) avaliaram os efeitos da aplicação de zinco, boro e AIB no enraizamento de estacas de Platanus acerifolia. 
Concluíram que a aplicação isolada de zinco e boro não influencia o enraizamento das estacas.

Mocelin et. al., (2000), testaram diferentes dosagens de AIB + B no enraizamento de estacas de Gaylussacia brasiliensis. Averiguaram que o tratamento de 4000 ppm de AIB + ácido bórico $150 \mathrm{ppm}$ na forma de solução foi o mais efetivo, atingindo $58 \%$ de enraizamento.

\subsubsection{Influência de carboidratos e outras substâncias sobre o enraizamento}

A capacidade de formação de raízes em estacas é devida a um sinergismo entre fatores inerentes às células $e$ as substâncias transportáveis produzidas nas folhas e gemas. Substâncias como: vitaminas, aminoácidos, açúcar (sacarose), compostos nitrogenados, carboidratos e outros compostos não identificados são utilizadas por pesquisadores adicionalmente às auxinas para incrementar a porcentagem de enraizamento das estacas (Janick, 1966; Costa Jr., 2000).

De forma geral, Hartmann \& Kester (1990) consideram que altos teores de carboidratos e baixos teores de nitrogênio, entre outros fatores, condicionam de um modo importante o bom enraizamento. Segundo os mesmos autores, os tecidos lenhosos, teriam maior disponibilidade de carboidratos que os novos e tenros, estes, estes, mais ricos em nitrogênio. Para Haissig (1974), a formação e o desenvolvimento do sistema radicular, requer nitrogênio para suprir a grande quantidade de ácidos nucléicos e proteínas. 
Segundo Lucchesi (1995), o grau de esclerificação do floema primário e a facilidade de enraizamento têm sido analisados nas espécies obtidas de semente. Os ramos de plantas jovens, quando comparados aos ramos de plantas adultas, apresentam menor quantidade de células escleróticas no floema primário. Detecta-se ainda, que as estacas retiradas da posição basal de um ramo enraízam melhor que aquelas das posições mediana e apical. O autor relata que em algumas espécies vegetais, há maior teor de carboidratos acumulados na região basal diminuindo em direção ao ápice do ramo, favorecendo assim o enraizamento das estacas retiradas da posição basal dos ramos. Tal fato não é uma regra geral, pois já foi detectado, em outras espécies, o inverso desse processo.

Cid et al., (1981) constataram, de fato, um alto teor de nitrogênio total nas estacas provenientes da parte superior dos caules, em relação às médias das outras estacas mais basais, o que pareceu influenciar negativamente o enraizamento de estacas de Pueraria phaseoloides.

O amido quando presente na estaca é tido como a mais importante fonte de carboidratos, responsável por municiar a energia necessária para a iniciação e o desenvolvimento radicular (Vieitz et al., 1980).

Ali \& Westwood (1986), ao trabalharem com estacas de oliveira, perceberam que o nível de enraizamento decresceu drasticamente de acordo com o nível de atividade vegetativa que se encontrava a planta matriz, chegando a ser nulo, quando a mesma permaneceu com inflorescências e frutos durante o processo de enraizamento. Tal explicação se dá pela diferente disponibilidade de hidratos de carbono 
em estacas vegetativas e frutíferas até o momento da preparação e durante e processo de enraizamento.

Hartmann \& Loreti (1965a), Mercado Flores \& Kester (1966) citam ainda, a influência da estação do ano sobre o enraizamento de estacas, fato estudado em vários cultivos. Essa variação na capacidade de enraizamento é atribuída às fases de crescimento da planta e ao estado bioquímico em que se encontra a estaca. Melleti et al., (2000), afirmam ser durante a primavera e início do verão que as plantas encontram-se em plena atividade vegetativa e com abundância de seiva circulante, enquanto que, no outono - inverno, encontram-se no período de repouso vegetativo.

Mukherjee et al., (1967), enquanto induziam com sucesso o enraizamento de plantas jovens de mangueira, descobriram que aquelas estacas originadas de seedlings de 1 mês de idade davam os mais elevados porcentuais de enraizamento, e com o aumento da idade das plantas matrizes, 3 anos e 10 anos respectivamente, o enraizamento reduzia consideravelmente. Estes autores compararam os níveis de enraizamento entre estacas oriundas de abieiros adultos e seedlings. Os autores constataram que $80 \%$ das estacas provenientes de seedlings enraizaram e as demais $20 \%$ apresentaram calo bem desenvolvidos. As estacas obtidas de abieiro adulto, não enraizaram $\mathrm{O}$ material oriundo de seedlings apresentou grande capacidade de retenção foliar enquanto que o obtido de plantas adultas apresentou grande perda de folhas.

Kalifa et al., (1964) realizando estudos fisiológicos em estacas de mangueira, afirmaram que o teor de substâncias inibidoras de enraizamento contidas nas mesmas sofre flutuações nas diferentes épocas do ano. 
Esta hipótese é confirmada por Fachinello et al., (1994), Bartolini, (1990), Elkassas et al., (1990) e Evert \& Smittle (1990). Segundo estes autores, o teor de carboidratos nos tecidos parece estar relacionado com a consistência das estacas, que varia durante o período anual. As estacas coletadas em um período de crescimento vegetativo intenso, primavera e verão, apresentam-se com poucas reservas de carboidratos e com consistência mais herbácea. Já estacas coletadas no inverno possuem um maior grau de lignificação e teores mais elevados de carboidratos. Essas observações também estão relacionadas aos níveis de fitohormônios dos tecidos, ou seja: estacas herbáceas possuem alta concentração de auxinas e baixa concentração de substâncias inibidoras do crescimento.

Vlachov (1988) realizou experimento com Platanus acerifolia e constatou que a capacidade de enraizamento de três tipos de estacas de ramos "do ano", obtidas ao longo da extensão do mesmo ramo (basais, medianas e apicais) foi significantemente diferente, sendo que as basais (mais lenhosas) apresentaram potencial superior, independente da época em que foram coletadas.

A resposta de enraizamento é afetada, ainda, pela temperatura. Essa influência pode ocorrer tanto no período do desenvolvimento dos ramos na planta matriz, quanto na estaquia propriamente dita. São consideradas ótimas para o enraizamento da maioria das espécies, temperaturas diurnas na faixa de 21 a $27^{\circ} \mathrm{C}$ e noturnas na faixa dos $15^{\circ} \mathrm{C}$ (Janick, 1966; Hartmann et al., 1990; Costa Jr., 2000).

Hansen (1989), menciona que a temperatura de $17^{\circ} \mathrm{C}$ por nove semanas, inibiu quase que completamente a emissão de raízes em Stephanotis floribunda; porém, com a temperatura inicial de $17{ }^{\circ} \mathrm{C}$ por duas, três ou quatro semanas após mantida a $23^{\circ} \mathrm{C}$, a 
percentagem de estacas de ramos enraizadas é de 92 a $98 \%$. O enraizamento paralisou com a manutenção da temperatura a $17^{\circ} \mathrm{C}$.

O ambiente em torno das estacas deve permanecer úmido ( $80 \%$ a $90 \%$ ) e algo mais fresco, o que se consegue mediante uso de nebulização intermitente (Hartmann \& Kester, 1980).

A umidade obtida de maneira correta, mantém vivas as estacas até que estas enraízem, pois forma uma película de água em torno da mesma. Esta película determina um menor ritmo respiratório, a redução da pressão de vapor interna da folha, culminando, na diminuição da transpiração, sem interferir na fotossíntese, o que origina um saldo positivo de assimilados imprescindíveis para a formação de raízes (Hartmann \& Kester, 1980; Rallo e del Rio, 1990; Oliveira, 2001).

\subsection{Juvenilidade}

Embora a vida dos tecidos pareça ser contínua, o ciclo de muitas espécies consiste em duas fases, nas quais, as características morfológicas e fisiológicas, são diferentes. Após a germinação da semente, a planta inicia uma fase de crescimento vegetativo muito vigorosa, durante o qual, a iniciação floral e a floração não podem ser induzidas, mesmo quando as condições externas são favoráveis. Esse período denomina-se período juvenil (Dunberg, 1977; Salisbury \& Ross, 1978 e Boliani, 1986).

De acordo com vários autores, a juvenilidade pode ser dividida em quantitativa e qualitativa. A primeira ocorre quando a planta está fisiologicamente apta para a floração, necessitando apenas de um estímulo externo, como por exemplo: a ocorrência de temperaturas 
favoráveis ao crescimento e desenvolvimento celular; estímulo provocado pelo fotoperiodismo ou a vernalização. A juvenilidade qualitativa ocorre quando a planta não está fisiologicamente apta para o florescimento.

Principalmente nas plantas de difícil enraizamento a juvenilidade acarreta algumas vantagens. Geralmente, tanto as estacas de ramos, como as de raiz tomadas de seedlings (fase juvenil de crescimento), enraízam mais facilmente quando comparadas com aquelas estacas tomadas de plantas já adultas. A fase juvenil possibilita o desenvolvimento vegetativo da planta e a produção de grande superfície foliar, necessária para a captação de energia solar, imprescindível para a realização da fotossíntese (Boliani, 1986).

Nas plantas, normalmente a região basal é mais juvenil que a região terminal. Segundo Hartmann \& Kester (1975) os meristemas mais próximos da base formaram-se em épocas mais próximas à germinação que os das regiões terminais. Normalmente, são utilizadas estacas oriundas de ramos juvenis, já que são capazes de formar raízes rapidamente.

Algumas características químicas e anatômicas dos caules e folhas, nas distintas fases foram averiguados por alguns autores. Foi encontrado que o material juvenil contém menor quantidade de amido, de açúcar, minerais e compostos nitrogenados, porém, mais celulose e lignina que o adulto; o tecido adulto, apresenta maior conteúdo de fibras no periciclo nas folhas que o juvenil Awad \& Castro (1983); Doorembos (1965).

Beakbane (1961), comparou material juvenil e adulto de algumas espécies e concluiu que há maior capacidade de enraizamento em estacas de material juvenil. Posteriormente, vários 
trabalhos surgiram evidenciaram a influência da juvenilidade associada ao emprego das substâncias de crescimento, no enraizamento de estacas.

Boliani (1986) cita inúmeros trabalhos de enraizamento de estacas de diversas espécies que evidenciam que houve maior porcentagem de estacas enraizadas, aumento de raízes primárias, maior comprimento das raízes a também aumento do número de raízes secundárias, resultados creditados à utilização de material em estado juvenil.

\subsection{Látex}

O látex é um fluido de composição complexa e muito variável tanto na aparência quanto na sua composição. É geralmente leitoso, mas pode ser incolor, marrom ou alaranjado. Freqüentemente contém borracha (um membro da família das substâncias orgânicas, denominadas terpenos) e as plantas que possuem grandes quantidades dessa substância em seus lacíferos são fontes naturais das borrachas utilizadas pela indústria. Muitas outras substâncias ocorrem nos látices (plural de látex) como, por exemplo, amidos, alcalóides, cristais, ceras, proteínas, taninos, açúcares e enzimas (a enzima proteolítica papaína, encontrada no mamão) (Frey - Wisslyng, 1955). 


\section{MATERIAL E MÉTODOS}

O primeiro experimento (experimento I) foi montado no dia 30 de março de 2001. Para esta primeira tentativa, as estacas testadas de Rédia e Abiu foram obtidas de plantas matrizes localizadas na coleção de frutíferas nativas e exóticas da Estação Experimental de Mococa do Instituto Agronômico de Campinas.

Foram utilizadas estacas com cerca de $10 \mathrm{~cm}$ de comprimento, provenientes da região apical de ramos, colhidos de plantas em pleno desenvolvimento. A colocação das estacas no substrato deu-se na profundidade de dois terços do comprimento da estaca, como o sugerido por Lucchesi (1995).

As estacas tratadas foram colocadas em bandejas de isopor, contendo substrato de vermiculita e dispostas em nebulização intermitente durante o período de enraizamento, em casa de vegetação do Departamento de Produção Vegetal da ESALQ/USP, em Piracicaba (SP). A casa de vegetação é formada por uma estrutura metálica revestida lateralmente com tela anti-afídeo e com plástico PEBD (Polietileno de baixa densidade) de 150 micra na cobertura.

Esta casa de vegetação conta com o controle de umidade, feito através dos nebulizadores do tipo "fogger" distribuídos uniformemente dentro da estrutura. O sistema de controle de umidade é feito por um sensor colocado na altura das bandejas e regulado para manter a 
umidade relativa em $90 \%$, como recomendam Hartmann \& Kester (1980).

Uma nova avaliação foi realizada no mês de dezembro de 2001, constatando mais uma vez, a morte generalizada das estacas de ambas as espécies.

Durante o mês de julho de 2001, repetiu-se o experimento, almejando a obtenção de resultados satisfatórios. Nessa segunda tentativa (Experimento II), as estacas receberam tratamento antifúngico. Foi utilizado o fungicida Benlate, na dose de $10 \mathrm{~g} /$ litro por 1 minuto. Autores como Hansen \& Hartmann (1966) e Piatkowski et al., (1973) confirmam que o tratamento fúngico melhora substancialmente o índice de enraizamento das estacas.

Para a Rédia utilizou-se a técnica de estiolamento, aumento das concentrações de AIB e utilização de ácido bórico. No dia 10 de dezembro de 2001 iniciou-se a preparação do experimento. Foi realizado o processo de estiolamento localizado em apenas uma parte do ramo visando a obtenção do estiolamento basal ou bandagem como recomendam Delargy \& Wright (1979), Figueiredo et al., (1995), Lopes (1995) e Reis (1999).

Diversos ramos, escolhidos aleatoriamente, receberam em sua parte mediana, uma camada de aproximadamente 4 a $5 \mathrm{~cm}$ de tinta látex preta (marca Suvinil).

No dia 26 de fevereiro de 2002 (77 dias após o estiolamento), as estacas foram coletadas com o auxílio de tesoura de poda. Paralelamente a este procedimento, foram coletadas estacas não estioladas, originando os experimentos "III A" e "III B".

No experimento "III A", as estacas foram imersas em solução de AIB (dissolvido em $\mathrm{KOH}$ ) + água destilada por 8 segundos 
(imersão rápida). Posteriormente, foram colocadas em bandejas de isopor, contendo substrato de vermiculita e dispostas em nebulização intermitente por aproximadamente 80 dias, quando foram avaliadas.

O delineamento experimental adotado foi o inteiramente casualizado, com 8 tratamentos e 3 repetições. Cada parcela foi composta por 15 estacas.

Total de estacas estioladas: 180; total de estacas sem estiolamento: 180 .

Os resultados foram submetidos à análise de variância, com o estudo da regressão para efeitos de concentração de AIB.

No experimento "III B" as estacas foram imersas em solução de AIB (dissolvido em $\mathrm{KOH}$ ) + água destilada e AIB (dissolvido em $\mathrm{KOH}$ ) + água destilada + ácido bórico. As estacas permaneceram imersas na solução de AIB por 18 horas (imersão lenta), como recomendado por Ono et al., (1990).

Posteriormente, foram colocadas em bandejas de isopor, contendo substrato de vermiculita e dispostas em nebulização intermitente por aproximadamente 80 dias, quando serão avaliadas.

O delineamento experimental adotado foi 0 inteiramente casualizado, com 10 tratamentos e 3 repetições. Cada parcela foi composta por 12 estacas. Total de estacas tratadas apenas com AIB: 180; total de estacas tratadas com AIB + ácido bórico: 180, totalizando 360 .

Os resultados foram submetidos à análise de variância, com o estudo da regressão para efeitos de concentração de AIB e do ácido bórico.

Uma nova metodologia foi desenvolvida a fim de viabilizar o enraizamento de estacas de abiu, considerando-se a ausência de 
resultados esperados. Para tanto, foram realizadas as seguintes mudanças no projeto original: diminuição das concentrações de AIB, assim como a troca da formulação em pó pela solução (AIB + água destilada); o emprego da técnica de lixiviação das estacas, visando eliminar o látex característico da espécie; e, talvez a mais significativa, a mudança da planta matriz. Esta nova etapa contou com estacas oriundas de plantas existentes no Viveiro de mudas da CATI em Tietê - SP, ao invés de utilizar as estacas das plantas da Estação Experimental de Agricultura de Mococa (IAC). Foram montados então, os experimentos "III a" e "III b".

A vasta bibliografia consultada evidenciou as vantagens da presença de folhas nas estacas, uma vez que, as mesmas garantem a sobrevivência das estacas, tanto pela síntese de carboidratos através da fotossíntese, como pelo fornecimento de auxinas e outros cofatores, que são importantes no processo de formação das raízes, estimulando a atividade cambial e diferenciação celular sendo que a fonte desses cofatores estaria nas folhas. Estes órgãos são poderosos produtores de auxina e os efeitos são observados diretamente abaixo da folha ou gema, indicando que existe um transporte do ápice para a base (Janick, 1966; Weaver, 1982; Hartmann \& Kester, 1983; Ono et al., 1996).

Com base nos fatos citados, optou-se por manter um par de folhas por estaca de abieiro.

Durante a manhã de 15 de março de 2002, foram colhidas 240 estacas. Posteriormente, foram colocadas em bandejas de isopor, contendo substrato de vermiculita e dispostas em nebulização intermitente por aproximadamente 180 dias, quando foram avaliadas. 
Realizaram-se dois experimentos, contando com 8 tratamentos, 3 repetições de 10 estacas /parcela. O primeiro foi montado com estacas lixiviadas em água destilada, trocada de duas em duas horas totalizando um período de 6 horas. Já no segundo experimento, foram utilizadas estacas não lixiviadas. Em ambos experimentos, as estacas foram expostas aos tratamentos descritos no item 3.1 ("III a" e "III $\left.b^{\prime \prime}\right)$.

Kalifa et al., (1964) realizando estudos fisiológicos em estacas de mangueira, afirmaram que o teor de substâncias inibidoras de enraizamento contidas nas mesmas sofre flutuações nas diferentes épocas do ano, sendo que, quando embebidas em água corrente por 24 horas, essas substâncias são mais facilmente eliminadas, melhorando a resposta de enraizamento.

As estacas permaneceram imersas na solução de AIB por 18 horas, como recomendado por Ono et al., (1990). Posteriormente, foram colocadas em bandejas de isopor, contendo substrato de vermiculita e dispostas em nebulização intermitente por aproximadamente 180 dias, quando foram avaliadas.

Variáveis a serem analisadas: número de brotações, número de estacas enraizadas, número de estacas sobreviventes, peso de raízes e número de folhas emitidas.

\subsection{Experimentos}

Para o enraizamento de estacas de Abiu e Rédia foram realizados os seguintes experimentos: 


\section{Experimento I - IBA em pó}

T1- talco inerte

T2- AIB a $1000 \mathrm{mg} \cdot \mathrm{L}-1$

T3- AIB a $2000 \mathrm{mg} . \mathrm{L}-1$;

T4- AIB a $4000 \mathrm{mg} \cdot \mathrm{L}-1$;

T5- AIB a 8000 mg.L-1.

\section{Experimento II - IBA em pó}

T1 - talco inerte

T2- AIB a $1000 \mathrm{mg} \cdot \mathrm{L}-1$;

T3- AIB a 2000 mg.L-1;

T4- AIB a $4000 \mathrm{mg} \cdot \mathrm{L}-1$;

T5- AIB a $8000 \mathrm{mg} . \mathrm{L}-1$.

\section{Experimento III (A) - Estiolamento + AIB}

T1- estiolamento + 0 ppm AIB;

T2- estiolamento +3000 ppm AIB;

T3- estiolamento +6000 ppm AIB;

T4- estiolamento + 12000 ppm AIB;

T5- sem estiolamento +0 ppm AIB;

T6- sem estiolamento +3000 ppm AIB;

T7- sem estiolamento +6000 ppm AIB;

T8- sem estiolamento + 12000 ppm AIB; 
Experimento III (B) - AIB + ácido bórico

T1- 0 ppm AIB;

T2- 50 ppm AIB;

T3- 100 ppm AIB;

T4- 200 ppm AIB;

T5- 400 ppm AIB;

T6- $0 \mathrm{ppm}$ AIB + $150 \mathrm{~g} / \mathrm{l}$ ácido bórico;

T7- 50 ppm AIB + $150 \mathrm{~g} / \mathrm{l}$ ácido bórico;

T8- 100 ppm AIB +150 g/l ácido bórico;

T9- 200 ppm AIB +150 g/l ácido bórico;

T10- 400 ppm AIB + $150 \mathrm{~g} / \mathrm{I}$ ácido bórico.

Experimento III (a) - Estacas lixiviadas + AIB:

T1- 0 ppm AIB;

T2- 100 ppm AIB;

T3- 200 ppm AIB;

T4- 400 ppm AIB.

Experimento III (b) - Estacas não lixiviadas + AIB:

T1- 0 ppm AIB;

T2- 100 ppm AIB;

T3- 200 ppm AIB;

T4- 400 ppm AIB. 


\section{RESULTADOS E DISCUSSÃO}

\subsection{Experimento I}

Após 107 dias, as estacas foram cuidadosamente separadas do substrato por meio de um jato de água e examinadas. Foi detectada em sua totalidade, a morte das estacas de Rédia e Abiu, sendo que, estas últimas, foram atacadas por fungos oportunistas, favorecidos pelas condições de estresse apresentadas pelas mesmas. A alta temperatura e a incidência de doenças sobre elas, pode ter sido a provável causa da alta mortalidade. Resultados semelhantes foram obtidos por Leonel et al., (1991), em trabalho com estacas de aceroleira e jaboticabeira.

\subsection{Experimento II}

Após 180 dias, embora a maioria das estacas de Rédia terem reagido vigorosamente, produzindo brotações e até flores e frutos, não se constatou qualquer indício de formação de raízes. Ao mesmo tempo, a grande semelhança de reação aos cinco tratamentos diferentes, sugeriu que: embora revelando que as condições gerais tenham sido bastante favoráveis à sobrevivência das estacas por 180 dias após a separação das matrizes, faltou algum fator indispensável 
para que houvesse a produção de raízes adventícias transformando as estacas em mudas frutícolas.

A emissão de ramos e folhas na estaca não é necessariamente sinônimo de enraizamento, pois muitas vezes a brotação prejudica a formação de raízes, uma vez que, as folhas passam a competir por nutrientes e promotores de crescimento contribuindo para que todas as reservas sejam exauridas e a brotação venha a provocar uma desidratação do material propagativo através da transpiração foliar, principalmente em estacas que iniciam o processo de brotação antes da iniciação radicular (Howard, 1978 e Chefins \& Howard, 1982).

Segundo Aroeira (1988), as estacas lenhosas têm um enraizamento mais lento que as herbáceas, e por ocasião da elevação da temperatura, pode ocorrer brotação de gemas e desenvolvimento de folhas, antes da formação de raízes.

Baseado na literatura e no que se observou, pode-se levantar as seguintes hipóteses, sobre as principais causas do insucesso em ambas as espécies:

a)- A estrutura anatômica dos tecidos amadurecidos de Rédia e Abiu, mostraram-se fisiologicamente inaptos a se diferenciarem, sendo desfavoráveis à produção de raízes adventícias (Knight, 1926; Hartmann \& Kester, 1990; Mes (1951).

b)- Klerk et al., (1990) afirmaram que o efeito inibitório do AIB no desenvolvimento dos primórdios radiculares deve-se à contínua divisão celular, que leva à formação de calo.

c) - A recente frutificação da planta matriz de Rédia, pode ter ocasionado o desvio dos hormônios que deveriam atuar na produção de raízes. Há ainda, a possibilidade de ter ocorrido certo desequilíbrio nutricional nas matrizes (de Abiu e Rédia), gerando um nível 
excessivamente baixo de nitrogênio no tecido dos ramos empregados; do mesmo modo, pode ter havido uma deficiência aguda de boro nas plantas e até mesmo a própria capacidade da estaca em formar raízes (Pearse, 1946).

d) - O tamanho e o tipo de estaca coletada exercem influência na iniciação radicular (Pearse, 1946; Hemberg, 1951; Sykes \& William, 1959).

\subsection{Experimentos "III A", "III B", "III a" e "III b"}

A época do ano, em que as estacas foram coletadas influiu no comportamento das mesmas, sendo que as estacas lenhosas de Rédia, coletadas em 26/02/2002 (pleno verão), apresentaram menor número de estacas mortas e brotos mais vigorosos. Volpe (1992) reforça esta hipótese, afirmando que a mortalidade talvez seja devida à fase de coleta das estacas, onde as plantas têm seu conteúdo de reservas reduzido. Quanto ao tipo de estaca, houve diferença entre o comportamento das estacas lenhosas apicais e subapicais de Abiu nas duas primeiras fases, havendo interação época $X$ tipo de estaca, o que ocorreu também com Almeida Neto et. al., (1989). Estes autores compararam os níveis de enraizamento entre estacas oriundas de abieiros adultos e seedlings. Os autores constataram que $80 \%$ das estacas provenientes de seedlings enraizou e as demais $20 \%$ apresentaram "callus" bem desenvolvidos. As estacas obtidas de abieiro adulto, não enraizaram $O$ material oriundo de seedlings apresentou grande capacidade de retenção foliar enquanto que o obtido de plantas adultas apresentou grande perda de folhas. 
Ali \& Westwood (1986) afirmam que uma elevada atividade vegetativa reduz o enraizamento de estacas de oliveira. Tal explicação se dá pela diferente disponibilidade de hidratos de carbono em estacas vegetativas e frutíferas até o momento da preparação e durante e processo de enraizamento. Em fevereiro/2002, época em que foi montada a segunda etapa do experimento, as plantas matrizes de Rédia encontravam-se em final de frutificação. Tal fato consolida as afirmações de Winkler et al., (1974) e Hartmann \& Kester (1990), de que deve-se evitar a retirada de estacas de plantas-mães que tenham apresentado um desenvolvimento vegetativo vigoroso seguido de produção elevada, pois todas as reservas foram mobilizadas por estes, e, ocorre produção de citocininas e giberelinas que são inibidoras do processo de iniciação de raízes. Bartolini et al., (1979) confirmam esta hipótese ao relatarem que os piores resultados alcançados em experimentos com enraizamento de estacas foram obtidos quando utilizou-se material oriundo de plantas matrizes em época de boa frutificação.

Pode ser que as dosagens de AIB nos tratamentos das estacas lenhosas foram insuficientes para promoverem o enraizamento.

A literatura cita alguns experimentos onde também não ocorreu influência positiva na aplicação de auxinas no enraizamento de estacas. Leonel \& Rodrigues (1993a), estudaram as interações entre os ácidos indol-butírico, alfa-naftaleno-acético e bórico no desenvolvimento de raízes em estacas de porta-enxertos de videira (Vitis vinifera L.). A pesquisa demonstrou que o IBA $2.000 \mathrm{ppm}+$ $\mathrm{H}_{3} \mathrm{BO}_{3} 150 \mathrm{mg} \cdot \mathrm{L}^{-1}$ propiciou o enraizamento em $88,87 \%$ das estacas, contudo não diferiu estatisticamente da testemunha $\left(\mathrm{H}_{2} \mathrm{O}-61,10 \%\right)$. Ainda no ano de 1993 (b), os mesmos autores avaliaram a eficiência 
do uso de IBA + ácido bórico em estacas de lichieira (Litchi chinensis). Este trabalho, porém, demonstrou que, dos tratamentos utilizados, nenhum foi efetivo na formação de raízes, havendo somente a formação de calos.

Pinto et al., (1963) relatam que ao testar a aplicação hormônios em citronela, não encontraram nenhuma influência sobre a brotação, enraizamento e crescimento.

Mendes (1959) utilizando o produto comercial "Radix" em regas quinzenais não obteve resultados satisfatórios no enraizamento de estacas de seringueira, enquanto que, Castro et al., (1984) observaram que a aplicação de AIB diluído em $\mathrm{KOH}$ causou necrose na base das estacas prejudicando o enraizamento.

Rossal \& Kersten (1997) detectaram resultados igualmente negativos ao testarem diferentes tratamentos com AIB no enraizamento de estacas de laranjeira cv. Valência. Os resultados mostraram que os tratamentos não influenciaram a formação de raízes.

Coutinho et. al., (1991), estudaram o enraizamento de estacas semi lenhosas de goiabeira serrana (Feijoa sellowiana), guabiju (Myrcianthes punces), cerejeira do mato (Eugenia involucrata), pitangueira (Eugenia uniflora) e araçá amarelo (Psidium cattlyanum) com o uso do AIB. Os autores verificaram que as estacas de guabiju, pitangueira e cerejeira do mato não enraizaram, mesmo quando tratadas com AIB. Por outro lado, as estacas de goiabeira serrana e araçá, apresentaram baixa porcentagem de enraizamento, com ou sem tratamento. Em 1992, o mesmo autor comprovou o insucesso, ao testar a eficiência do AIB no enraizamento de estacas de goiabeira 
serrana (Feijoa sellowiana), detectou que os tratamentos utilizados não induziram o enraizamento das estacas.

Em contrapartida, inúmeros trabalhos citam que a aplicação de auxinas e auxinas + boro favoreceu o enraizamento de estacas de difícil enraizamento. Jarvis et al., (1984), detectaram maior desenvolvimento das raízes em estacas de P.aureus, favorecido pelo aumento da concentração de IBA, principalmente quando essas estacas eram tratadas com ácido bórico à $150 \mathrm{mg} \cdot \mathrm{L}^{-1}$, o que levou ao máximo de crescimento das raízes.

Scarpare Filho et. al., (1999) ao trabalharem os efeitos do AIB no enraizamento de estacas de jaboticabeira, verificaram que não houve enraizamento de estacas sem utilização do promotor de enraizamento, enquanto que o AIB promoveu níveis de até 37,98\%, dependendo da concentração, além de ter possibilitado um aumentado na sobrevivência das estacas.

Zuffellato-Ribas et al., (2000), concluíram que o melhor tratamento, responsável por $86 \%$ de estacas de Ficus enormis enraizadas, foi a aplicação de $4000 \mathrm{mg} \cdot \mathrm{L}^{-1} \mathrm{IBA}+150 \mathrm{mg} \cdot \mathrm{L}^{-1}$ ácido bórico, comprovando o fato de o ácido bórico ser considerado um cofator do enraizamento.

Mocelin et. al., (2000), testaram diferentes dosagens de AIB+B no enraizamento de estacas de Gaylussacia brasiliensis. Averiguaram que o tratamento de 4000 ppm de AIB + ácido bórico 150 ppm na forma de solução foi o mais efetivo, atingindo $58 \%$ de enraizamento.

Fadl et al., (1986) obtiveram $86,7 \%$ de enraizamento ao testarem o tratamento de AIB a $400 \mathrm{ppm}+0,5 \%$ de boro, em experimento realizado durante o mês de janeiro. 
Resultados positivos ainda foram registrados por Nachtigal \& Fachinello (1995), ao trabalharem com estacas de araçazeiro, Nachtigal et. al., (1999) ao estudarem a propagação do umezeiro, Pereira et. al., (1995) ao testarem os efeitos do AIB no enraizamento de estacas de goiabeira, além de numerosos casos citados na literatura.

O estiolamento como um dos processos que favorecem o enraizamento, mostrou resultados pouco significativos, contrariando as informações da literatura, as que, segundo Bid \& Mukherjee (1969) com mangueira, Rodrigues \& Lucchesi (1987) com guaranazeiros e

Sampaio (1989) com laranja Pêra, afirmaram que esta técnica, principalmente em associação com outras, têm sido fundamental para o sucesso no enraizamento de estacas com folhas. Por outro lado, Casagrande Jr. et al., (2001), ao testarem o efeito do estiolamento de ramos e do AIB em estacas de jaboticabeira, explicam que não houve efeito dos tratamentos na porcentagem de estacas enraizadas. De acordo com eles, o estiolamento agiu de forma negativa, diminuindo o número de estacas brotadas e favorecendo a morte das mesmas.

Outros métodos que poderiam ser utilizados em novas tentativas para promover o enraizamento de estacas de Rédia e Abiu seriam o anelamento, que trouxe resultados positivos em vários trabalhos citados pela literatura consultada ou a combinação destes e outros métodos também coma aplicação de auxinas.

Enfim, vários fatores podem ter influído no não enraizamento das estacas de Abiu e Rédia, sendo necessário para isso, experimentos mais detalhados analisando o conteúdo de carboidratos e micronutrientes das estacas, isolamento e bioensaio de possíveis 
substâncias promotoras e inibidoras de enraizamento e análises detalhadas da anatomia das estacas. 


\section{CONCLUSÕES}

Não se pode afirmar que seja impossível o enraizamento de estacas caulinares de Rédia e Abiu, todavia pode-se concluir que trata-se de espécies de difícil enraizamento de estacas caulinares.

A utilização de diferentes tipos de estacas e épocas de coleta não surtiram efeito, tampouco as técnicas tradicionalmente utilizadas como a aplicação de ácido indolbutírico e boro e o estiolamento e lixiviação testados no enraizamento de estacas.

Os experimentos realizados indicaram que se faz necessário um estudo mais detalhado de anatomia e fisiologia das espécies de Rédia e Abiu para determinar, se possível, a causa do não enraizamento, ou ainda, a aplicação de outras técnicas como a microestaquia, a utilização de inibidores da síntese de giberelinas, ou até mesmo a alporquia - esta, por ser mais viável econômica e tecnologicamente ao produtor -. 


\section{REFERÊNCIAS BIBLIOGRÁFICAS}

ADRIENCE, G. W.; BRISON, F. R. Propagation of horticultural plants. New York: Hill Book, 1939. 314 p.

ALCAZAR, J. T. E. Los recursos fitogenéticos: una inversión para el futuro. Madrid: Conselho Internacional de Recursos Fitogenéticos, 1983. $44 \mathrm{p}$.

ALVARENGA， L. R. de.; CARVALHO, V. D. Uso de substâncias promotoras de enraizamento de estacas frutíferas. Informe Agropecuário. v. 9, n. 101, maio/1983. p. 47-55.

ALI, N.; WESTWOOD, M.N Rooting of pear cuttings as related to carbohydrates, nitrogen and rest period. Proceedings of the American Society Horticultural Science, v. 88, p. 145-150, 1986.

ALTMAN, A.; WAISEL, Y. (Ed.). Biology of root formation and development. In: INTERNATIONAL SYMPOSIUM ON THE BIOLOGY OF ROOT FORMATION AND DEVELOPMENT, 2., Proceedings. New York: Plenum, 1996, p. 376. 
ANTUNES, L.E.C. Influência de diferentes períodos de estratificação, concentrações de ácido indolbutírico e substratos no enraizamento de estacas de figueira (Ficus carica L.). Lavras, 1995. 53 p. Dissertação (M.S) - Universidade Federal de Lavras.

ARENS, T.; ARENS, K. O enraizamento de eucalyptus no clima de São Paulo. Ciência e Cultura, v. 3, n. 24, p. 233-278, 1972.

AROEIRA, J. S. Da estaquia: princípios gerais e aplicação em horticultura. Revista Ceres, v. 10, n. 57, p. 211-223, 1988.

AVERY JR., G.S.; JOHNSON, E.B. Hormones and the rooting of cuttings. Hormones and horticulture; the use of special chemicals in the control of plant growth. New York: McGrawHill,. 1947, p. 13-121. (McGraw-Hill Publications in the Botanical Sciences).

AWAD, M.; CASTRO, P.R.C. Introdução à Fisiologia Vegetal. São Paulo: Nobel, 1983. 177 p.

BARTOLINI, G.O. Improving rooting and survival of hardwood peach cutting. In: INTERNATIONAL HORTICULTURAL CONGRESS, 23., Firenze, 1990. ANAIS Bolonha: Tecnoprint, 1990, p. 190. BARTOLINI, G.; TRONCOSO, A.; FIORINO, P. Radicazione di talle di olivo cv. "Frangivento" provenienti da piante madre allevate in ambienti diversi. Rivista Ortoflorofruttcoltura Italiana, v. 63, p. 269-278, 1979.

BASSUK, N.; MAYNARD, B. Stock plant etiolation. HortScience. v. 22, n. 5, p. 749-750, 1987.

BASSUK, N.; MAYNARD, B.; CREEDON, J. Stockplant etiolation and banding for softwood cutting propagation: working towards commercial application. International Plant Propagators Society, v. 36, p. 599-604, 1987. 
BASSUK, N.; MYSKE, D.; MAYNARD, B. Stock plant etiolation for improved rooting of cuttings. International Plant Propagators Society, v. 35, p. 543-550, 1985.

BEAKBANE, V.R. Struture of the plant stem in relation to adventitious rooting. Nature, n. 192, v. 9, p. 954-955, 1961.

BERTELL, G.; ELIASSON, L. Cytokinin effects on root growth and possible interactions with ethylene and indole-3-acetic acid. Physiologia Plantarum, n.84, p. 255-261, 1992.

BEZERRA, J. E. F.; LEDERMAN, I. E.; PEDROSA A. C.; DANTAS A. P.; NETO L. G.; PEREIRA, R. C. A.; NETO, M. L. M. Coleta e preservação de espécies frutíferas tropicais nativas e exóticas em Pernambuco. In: SIMPÓSIO LATINO-AMERICANO SOBRE RECURSOS GENÉTICOS DE ESPÉCIES HORTÍCOLAS, Campinas, 1990. Anais. Campinas:Fundação Cargill, 1990, p. 140-147.

BIASI, L. A. Emprego do estiolamento na propagação de plantas. Ciência Rural, , v. 26, n. 2, p. 309-314, 1996.

BID, N. N.: MUKHERJEE, S. K. Varietal response to estiolation and growth regulator treatment in air-layering of mango (Mangifera indica L.). Indian Journal of Agricultural Science, v. 39, p. 1013-1019, 1969.

BLAZICH, F. A. Mineral nutrition and adventitious rooting. In: DAVIS, T.D; HAISSIG, B.E.; NARENDRA, S. (Ed.). Adventitious root formation in cuttings. Oregon: Dioscorides Press, 1988, v.2, p. 61-69. 
BOLIANI, A. C. Efeitos do estiolamento basal, da juvenilidade e do uso de um regulador vegetal no enraizamento de estacas de raízes e ramos herbáceos de algumas espécies frutíferas. Piracicaba, 1986. 129 p. Dissertação (Mestrado) Escola Superior de Agricultura "Luiz de Queiroz", Universidade de São Paulo.

BROWSE, P. M. A propagação das plantas. 2 ed. Mem Martins: Publicações Europa-América, 1979, 229 p. (Coleção Euroagro, 8). BUNT, A.C. Peat-sand composts: Their volue in raising and growing ornamental plants. I. General priciples. Journal of the Royal Horticultural Society, v. 96, p. 29-33, 1971.

CARY, A. J.; LIU, E.; HOWELL, S. H. Cytokinin action is coupled to ethylene in its effects on the inhibition of root and hypocotyl elongation in Arabidopsis thaliana seedlings. Plant Physiology, n.107, p.1075-1082, 1995.

CASAGRANDE JUNIOR., J. G.; DUTRA, L. F.; TONIETTO, A; NACHTIGAL, J. C.; STRELOW, E. Efeito do estiolamento de ramos e do AIB no enraizamento de estacas herbáceas de jabuticabeira. Revista Brasileira de Agrociência, v.7, n.2, 2001. http://www.ufpel.tche.br/faem/agrociencia/rev7n2.htm\#5 (27.agosto.2001).

CASTRO, P. C. C.; Reguladores vegetais: modos de ação e aplicação na agricultura tropical. Informações Agronômicas, n. 78, p. 5-7, 1997.

CASTRO, P.R.C.; FACHINELLO, J.C.;FAQUIM, V.; RAMALHO, J.F.G.P.; BACCHI, O.O.S. Estimulação do enraizamento de estacas de seringueira (Hevea brasiliensis Muell.Arg.). Anais da ESALQ, n. 41 , v. 1, p. 349-357, 1984. 
CHEFFINS, N. J.; HOWARD, B.H. Carboydrate changes in leafless winter apple cuttings. The influence of level and duration of bottom heat. Journal of Horticultural Science, v. 1 , n. 57, p. 1$8,1982$.

CID, L.P.B.; FIALHO, J.F. de; NEVES, M.A.C. Influência de diferentes concentrações de ácido 3-indol-acético mais boro e de teores de carboidratos e nitrogênio no enraizamento de estacas de Pueraria phaseoloides. Pesquisa Agropecuária Brasileira, v. 16, n. 5, set./out., p. 623-626, 1981.

CLEMENT, C.R. A center of crop genetic diversity in Western Amazonia. BioScience, n. 39, p. 624-631, 1996.

COHEN, J. D; BANDURSKI, R. S. Chemistry and physiology of the bound auxins. Annual Review Plant Physiology, n.33, p.403430, 1982.

COSTA JUNIOR., W. H. da Enraizamento de estacas de goiabeiras: Influência de fatores fisiológicos e mesológicos. Piracicaba, 2000. 66 p., Dissertação - (Mestrado) - Escola Superior de Agricultura "Luiz de Queiroz", Universidade de São Paulo.

COUTINHO, E. F.; MIELKE, M. S.; ROCHA, M. S.; DUARTE, O. R. Enraizamento de estacas semi-lenhosas de fruteiras nativas da família Myrtaceae com o uso do ácido indolbutírico. Revista Brasileira de Fruticultura, v. 13, n.1, p. 167-171, 1991.

COUVILLON, G. A. Rooting responses to different treatments. Acta Horticulturae. v. 227, p. 187-196, 1988.

COUVILLON, G. A.; EREZ, A. Rooting, survival, and development of several peach cultivars propagated from semihardwood cuttings. HortScience, v. 15, n. 1, p. 41-43, 1980. 
CUQUEL, F.L. Enraizamento de estacas de crisântemo Dendranthema morifolium tratadas com ácido indolbutírico. Piracicaba, 1992, 66 p. Dissertação - (Mestrado) - Escola Superior de Agricultura "Luiz de Queiroz", Universidade de São Paulo.

DAVIS, P.J. Plant hormones and their role in plant growth development. Dorchect:Martinus Nijhaff, 1987. 618 p.

DAVIES, P.J. The plant hormones concept: concentration, sensitivity and transport. In: DAVIES, P. J. (Ed.). Plant hormones: physiology, biochemistry and molecular biology. Dorderecht, Kluwer Acad., 1995, p. 13 - 38.

DELARGY, J. A., WRIGHT, C. E. Root formation in cutting of apple in relation to auxin application and to etiolation. New Phytologie., $v$. 82, p. 341-347, 1979.

De VIER, C. L.; GENEVE, R. L. Flowering influences adventitious root formation in chrysanthemum cuttings. Scientia Horticulturae, v. 70, p. 309-318, 1997.

DIAZ, J.C.H.; SANTIAGO, M.A.M. Estúdio de algunos factores que afectam el prendimiento de estacas duras de Populus y Acer em Chapingo, México (Populus Alba L.). Chapingo, n. 9, p. 3-9, 1978. DOOREMBOS, J. Juvenile and adult phases in woody plants. Enciclopedia of Plant Physiology, v. 1, n. 15, p. 1222-1235, 1965.

DUMBERG, A. Juvenile maturation aging and rejuvenation in woody plants. In: SIMPÓSIO DE UPSALA, Sweden. VEGETATIVE PROPAGATION OF FOREST TREES-PHYSIOLOGY AND PRATICES. Upsala, 1977, Anais Upsala:Pergamon Press, 1977. 175 p.

EDMOND, J. B., SENN, T. L., ANDREWS, F. S. Princípios de horticultura. México: Compañia Editorial Continental, 1967. 575 p. 
ELIASSON, L.; BRUNES, L. Ligth effects on root formation in aspen and willow cuttings. Physiologya Plantarum, n. 48, p. 261265, 1980.

ELKASSAS, S.E.; ELAGAMY, S.Z; ELSESE, A.M. Physiological studies on rooting ability of "Sultani" and "Abiad Asswan" fig cuttings. In: INTERNATIONAL HORTICULTURAL CONGRESS, Firenze, Italy, 1990. Anais Bolonha: Tecnoprint, 1990, 189 p.

ESAU, K. Anatomia das plantas com sementes. Trad. Berta Lange de Morretes. São Paulo: Edgard Blücher, 1997. 293 p.

ESCOLA SUPERIOR DE AGRONOMIA "LUIZ DE QUEIROZ" Normas técnicas para elaboração de dissertações e teses. 2 ed., Piracicaba: ESALQ, 1997, 94 p.

EVERT, D.; SMITTLE, D. Carboydrates and survival in peach cuttings when field-rooted during mild winters. In: INTERNATIONAL HORTICULTURAL CONGRESS, 23., Firenze, Italy. 1990 Anais Bolonha: Tecnoprint, 1990, p. 187.

FACHINello, J. C.; HOFfMAnN, A.; NACHTIGAL, J. C. Propagação de plantas frutíferas de clima temperado. Pelotas:UFPEL, 1994. $179 \mathrm{p}$.

FACHINELLO, J. C.; HOFFMANN. A.; NACHTIGAL, J. C.; KERSTEN, E.; FORTES, G. R.de L. Propagação de plantas frutíferas de clima temperado. 2 ed. Pelotas: UFPEL, 1995. 178 p.

FADL, M.S.; SOUIDAN, M.A.; ZAYED, M.M.; HAMMODA, A. Studies on using IBA and other chemicals in rooting pear cuttings. Al-Azhar, Annals of Agricultural Science, v. 1, n. 24, p. 234-254, 1986. Resumo em Horticultural Abstract, East, v. 8, n. 58, p. 520, 1988. 
FAHN, A. Plant anatomy. 2 ed. New York: Pergamon Press, 1974. $611 \mathrm{p}$.

FAHN, A. Anatomia vegetal. 3 ed., Madrid:Pirâmide, 1982. 599 p. FOOD AND AGRICULTURE ORGANIZATION. (htpp://www.fao.org). (20. jul.2002).

FERREIRA, B. G. A.; ZUFFELLATO-RIBAS, K. C.; CARPANEZZI, A. A.; TAVARES, F. R. Efeitos dos ácidos indol-butírico e bórico no enraizamento de estacas de Sapium glandulatum. In: CONGRESSO NACIONAL DE BOTÂNICA, 51., Brasília, 2000. Resumos. Brasília: Universidade de Brasília, 2000. p. 44.

FIGUEIREDO, S. L. B.; KERSTEN, E.; SCHUCH, M. W. Efeito do estiolamento parcial e do ácido indolbutírico (IBA) no enraizamento de estacas de ramos de goiabeira serrana (Feijoa sellowiana, Berg.). Scientia Agrícola, v. 52, n. 1, p. 167-171, 1995.

FMI, Fundo Monetário Internacional. htpp://www.imf.org.

(20.jul.2002).

FREY - WISSLYNG, A. The phloem supply to the nectaries. Acta Botanical, n. 4, p. 358-369, 1955.

FROLICH, E. F. Rooting guatemalan avocado cutting. California Avocado Society Yearbook, v. 36, p. 136-138, 1951.

FROLICH, E. F. Use of the etiloation technique in rooting avocado cutting. California Avocado Society Yearbook, v. 55, p. 97109, 1972.

FRUITLOVERS. http://www.fruitlovers.com/bacuri.html. $(27$. agosto.2001).

GABRIELS, R.; VERDONCK, O. MEKERS, O. Substrate requirements for pot plants in recirculationg water culture. Acta Horticulturae, v. 178, p. 93-99, 1986. 
GARCIA, M. T.; BALLESTER, A.; VETTIEZ, E. Variation on el contenido de almidon en estaquillas juvenilles de castaño y su relacion en el enraizamiento. Anales de Edafología y Agrobiologia, v. 11/12, n. 41, p. 2281-2286, 1982.

GARDNER, F. E. Etiolation as a method of rooting apple variety stem cuttings. Proceedings American Society for Horticultural Science. v. 34, p. 323-329, 1936.

GAUCH, H. G.; DUGGER, W. M. JUNIOR. The role of boron in the translocation of sucrose. Plant Physiology, v. 28, p. 457-466, 1953.

GONÇALVES, A. L.; MINAMI, K. Efeito de substrato artificial no enraizamento de estacas de calanchoe (Kalanchoe $x$ blossfeldiana cv. Singapur, Crassulaceae). Revista Scientia Agrícola, v. 51, n. 2, p. $240-244,1994$.

GONZÁLEZ, M. G.N.; SCHIMIDT, C. A. P. Estudo do efeito de duas concentrações de ácido indolbutírico (IBA) e ácido naftaleno acético (ANA) no enraizamento de estacas herbáceas de goiabeira (Psidium guajava L.) CV. Kumagai. Revista Brasileira de Fruticultura, v. 14, n. 3, p. 229-232, 1992.

GRUNBERG, J. P. El arte de criar e injetar frutales. 2 ed. Buenos Aires:Franco, 1928. 204 p.

GUIMARÃES, C. L.; LUZZI, R.; VERDI, L. G.; SIMIONATTO, E. L.; DELLEMONACHE, F.; YUNES, R. A.; FLORIANI, A. E. O.; CECHINEL, $V$. Isolation of biflavonoids with analgesic activity from Rheedia gardneriana leaves. PHYTOMEDICINE, v. 4, n.2, p. 141-144, jun., 1997; RESUMOS DE ARTIGOS INDEXADOS: http://home.furb.br/clg/resumo.htm, (20.agosto.2001). 
HAISSIG, B. E. Metabolism during adventitious root primordium initiation and development. New Zealand Journal Forestry Science. v. 4, n.2, p. 324-337, 1974.

HAISSIG, B.E. Metabolic process in adventitious rooting of cuttings. In: JACSON, M.B. New rooting formation in plants and cuttings. Dordrecht:Martinus Nijhoff, 1986. 189 p.

HANSEN, C.J.; HARTMANN, H.T. Propagation of temperate-zone fruit plant. California Agricultural. v. 471, 1966, p.40-45; 47-49.

HANSEN, J. Influence of cutting position and temperature during rooting on adventitious root formation and axilary bud break of Stephanotis floribunda. Scientia Horticulturae, n. 40, p. $345-$ $354,1989$.

HANSEN, O. B.; POTTER, J. R. Rooting of Apple, Rhododendron and Mountain Laurel cuttings from stock plants etiolated under two temperatures. HortScience, v. 32, n. 2, p. 304-306, 1997.

HANSON, C. K. The effect of indolebutyric acid on rooting Lovell and Nemaguard peach cuttings. HortScience, v. 13, n. 3, p. 374, 1978.

HARBAGE, J. F.; STIMART, D. P.; EVERT, R. F. Anatomy of adventitious root formation in microcuttings of Malus domestica Borkh. "Gala". Journal of the American Society for Horticultural Science, v. 118, n.5, p.680-688, 1993.

HARTMANN, H. T., KESTER, D. E. Propagación de plantas (Plant Propagation) México: Compañía Editorial Continental, 1964. 813 p. HARTMANN, H. T., LORETI, F. Seasonal variation in rooting leafy olive cuttings under mist. Proceedings American Society Horticulture Science, v.87, p.194-198, 1965. 
haRTMAnN, H. T., KeSTeR, D. E. Propagación de plantas. México: Continental, $1975.810 \mathrm{p}$.

HARTMANN, H. T.; HANSEN, C. J. Effect of season of collecting, indolbutiric acid and pre-planting storage treatments on rooting of Marianna plum, peach and quince hardwood cuttings. Proccedings of the American Society for Horticultural Science, v. 71, n. 1, p. 57-66, 1958.

HARTMANN, H. T., KESTER, D. E. Propagacion de plantas, principios y practicas. Mexico:CECSA, 1980. $814 \mathrm{p}$.

HARTMANN, H. T., KESTER, D. E. Plant propagation; principles and pratices: New York: Englewood Clipps, Prentice-Hall, 1983, $727 \mathrm{p}$.

HARTMANN, H. T., KESTER, D. E. Propagación de plantas: princípios y practicas. México: Compañia Editorial Continental, 1990. 760 p. HARTMANN, H. T.; FloCKER, W. J.; KOFRAWEK, A. M. Plant Science growth, development and utilization of cultivated plants. New Jersey: Prentice-Hall, 1981. $676 \mathrm{p}$.

HELLER, A.; BOROCHOV, A.; HALEVY, A. H. Factors affecting rooting ability of Coleonema aspalathoides. Scientia Horticulturae, v.58, p.335-341, 1994.

HEMBERG, T. Rooting experiments with hypocotyles of Phaseolus vulgaris. Acta Horticulture. n.4, p. 358-369, 1951.

HESS, C. E. Internal and external factors regulatig root initiation; root growth. London: Buttersworth, 1969, p. 42-53.

HOWARD, B. H. Field establishment of apple rootstock hardwood cuttings as influenced by conditions during a prior storage in heated bins. Journal Horticultural Science. v. 53, n.1, p. 31-37, 1978. 
HWANG, K.S. Studies on factors affecting the rooting of peach cuttings. Journal of the Korean Society for Horticultural Science. v.2, n.28, p. 137-152, 1987. Resumo em Horticultural Abstract, n. 58, v. 9, set/1988, p. 602. (Resumos).

INSTITUTO BRASILEIRO DE FRUTICULTURA. Fruticultura: Síntese. (http://www.ibraf.org.br/x-es/f-esta.html). (20.jul.2002).

IRITANI, G.; Ação de reguladores do crescimento na propagação por estaquia de Ilex paraguaiensis. Saint Hilaire e Araucaria angustifolia (Bert.). O. KTZE. Curitiba, 1981. 163 p. Dissertação (Mestrado) - Universidade Federal do Paraná.

JACKSON, M. New root formation in plants and cuttings. Boston: Martius Nifhaft, 1986. 286 p.

JANICK, J. A ciência da horticultura. Rio de Janeiro:USAID, 1966. 485 p.

JARVIS, B. C.; YASMIN, S.; ALI, A.N.H. The interation between auxin and boron in adventitious root development. New Phytologistic, v. 97, n. 2, p. 197-204, 1984.

KALIFA, A.S.; EL-AZOOUNI, M.M.; WALI, Y.A. Physiological studies on mango cuttings. The Indian Journal of Horticulture, $v$. 21, n.3/4, p. 179-185, 1964.

KAWASE, M. Etiolation and rooting in cuttings. Physiologya Plantarum, v. 18, p. 1066-1076, 1965.

KERSTEN, E. Efeito do Boro, Zinco e Ácido Indol-butírico no enraizamento de estacas de dois cultivares de ameixeira (Prunus salicina, Lindl.). Piracicaba, 1990, 112 p. Tese (Doutorado) - Escola Superior de Agricultura "Luiz de Queiroz" - Universidade de São Paulo. 
KLERK, G. J.; SMULDERS, R.; BENSCHOP, M. Basic peroxidases and rooting in microcuttings of Malus. Acta Horticulturae, v.280, p. 29-36, 1990.

KNIGHT, R. C. The propagation of fruit tree stocks by stem cuttings. In: Observations on the factors governing rootings of hardwood cuttings. Journal Pomologic and Horticulture Science, n. 5, p. 248-266, 1926.

La RUE, C. D. Root-grafiting in tropical trees. Science, n. 115, v. 296, p. 52-58, 1952.

LEONEL, S.; VARASQUIM, L. T.; RODRIGUES, J. D.; CEREDA, E. Enraizamento de estacas de acerola (Malpighia glabra Linn). Revista Brasileira de Fruticultura. v. 13, n. 3, p. 213-217, 1991.

LEONEL, S.; RODRIGUES, J. D.; Efeito da época de estaquia, fitorreguladores e ácido bórico no enraizamento de estacas de porta-enxertos de videira. Scientia Agricola. v. 50, n. 1, fev./maio, p. 27-32, 1993a.

LEONEL, S.; RODRIGUES, J. D.; Efeitos da aplicação de reguladores vegetais e do ácido bórico, em estacas de lichieira (Litchi chinensis SONN.). Scientia Agricola. v. 50, n. 1, fev./maio, p. 33-39 1993b.

LINSINGEN, L. VON; ZUFFELLATO-RIBAS, K. C.; W.; CARPANEZZI, A. A.; TAVARES, F. R. Propagação vegetativa de Erytrina speciosa (Andrews) através do uso de fitorreguladores. In: CONGRESSO NACIONAL DE BOTÂNICA, 51., Brasília, 2000, Resumos. Brasília: Universidade de Brasília, 2000, p. 45. 
LORENZI, H. Árvores Brasileiras: Manual de Identificação e

Cultivo de Plantas Arbóreas Nativas do Brasil., Nova Odessa:

Ed. Plantarum, 1992, p. 119.

LOVELL, P. H.; WRITE, J. Anatomical changes during adventicious root formation. In: JACKSON, M. B. (Ed.). New root formation in plants and cuttings. Dordrecht: Martinus Nijhoff, 1986. p. 111140.

LUCCHESI, A. A. Aspectos fisiológicos relacionados à propagação vegetativa por estaquia. Artigo Técnico, NOTESALQ, v. 4, n. 6, p. 4-5, 1995.

MATTOS, J. R. Fruteiras nativas do Brasil com potencial para a América Latina. In: SIMPÓSIO LATINO AMERICANO DE RECURSOS GENÉtICOS VEgETAIS, 1., Campinas, 1997. Anais. Campinas:Editora, 1997.

MAYNARD, B. K.; BASSUK, N. L.; Etiolation and effects on adventious root formation. In: DAVIES, T. D., HAISSING, B. E.., SANKHLA, N. (Ed.). Adventitious root formation in cuttings. Portland: Dioscorides Press, 1988, v. 2, p. 29-46.

MAYNARD, B. K.; BASSUK, N. L.; Rooting softwood cuttings of Acer griseum: Promotion by stockplant etiolation, inhibition by catechol. HorScience, v. 25, n. 2, p. 200-204, 1990.

MEDRADO, M.S.J. Fatores relacionados ao processo de propagação da seringueira (Hevea spp.) em Piracicaba, SP. Piracicaba, 1992. 178 p. Tese (Doutorado) - Escola Superior de Agricultura "Luiz de Queiroz" - Universidade de São Paulo.

MELETTI, L. M. M.; FOLTRAN, D. E.; TEIXEIRA, L. A. J.; SOARES, N. B.; COELHO, S. M. B. M.; SARMENTO, B. M. M. de; Propagação de frutíferas tropicais. Guaíba: Agropecuária, 2000. 239 p. 
MENDES, L.O.T. A multiplicação da seringueira (Havea brasiliensis Mell-Arg.) por meio de estacas. Bragantia, n. 18, v. 1, p. 245$274,1959$.

MENGEL, K.; KIRKBY, E. A. Principles of plant nutrition. Worblaufer-Bern: International Potash Institute, 1979. 579 p. MERCADO FLORES, I., KESTER, D. E. Factors affecting the propagation of some interspecific hybrids of almond by cuttings. Proceedings American Society Horticultural Science. v. 88, p. 224-231, 1966.

MES, M.G. Cuttings difficult to root. Plants and Gardens, n.7, v.2, p. 95-97, 1951.

MIDDLETON, W.; JARVIS, B. C.; BOOTH, A.; The boron requirement for root development in stem cutting of Phaseolus aureus. New Phytologie. p. 81-287, 1978.

MINISTÉRIO da AGRICULTURA.

(http://www.agricultura.gov.br/dfpv/fruticultura.htm) (19.jul.2002).

MOCELIN, E. Z., ZUFFELLATO-RIBAS, K. C., CARPANEZZI, A. A., TAVARES, F. R. Relação entre as épocas do ano e o enraizamento de estacas herbáceas de camarinha (Gaylussacia brasiliensis). In: CONGRESSO NACIONAL DE BOTÂNICA, 51. Brasília, 2000, Resumos. Brasília: Universidade de Brasília, 2000. p. 44. MOE, R.; ANDERSEN, A. S. Stock plant enviroment ans subsequent adventitious rooting. In: DAVIS, T. D.; HASSIG, B. E.; SANKHLA, $H$. (Ed.). Adventitious root formation in cutting. Portland, Oregon: Discorides Press. 1988. p. 214-234. 
MOHAMED, S.; SORHAINDO, C. A. Production and rooting of etiolated cutting of west Indian and hybrid avocado. Tropical Agriculturist, v. 61, n. 3, p. 200-204, 1984.

MONTERO, F. P.; AGUERA, E.; JIMENEZ, F. Comparative effect of different growth regulators and boron on rooting of carnation cuttings. Agrochimica, n. 29, p. 356-363, 1985.

MUKHERJEE, S.K.; MAJUNDER, P.K.; BID, N.N.; GOSWANI, A.M. Standardization of rootstocks of mango. II. Studies on the effects of source, invigoration an etiolation on the rooting of mango cuttings. Journal of Horticultural Science, v.42, p. 83-87, 1967.

MURRAY, H. R.; TAPER, C. D.; PICKUP, T. NUSSEY, A. N. Boron nutrition of softwood cuttings of geranium and currant in relation to root development. Proceedings American Society Horticultural Science., v. 69, p. 498-501, 1957.

NACHTIGAL, J.C; FACHINELLO, J.C. Efeito de substratos e do ácido indolbutírico no enraizamento de estacas de araçazeiro (Psidium cattleyanum). Revista Brasileira de Agrociência, v.1, n.1, jan/abr., p. 34-39, 1995.

NACHTIGAL, J. C.; PEREIRA, F. M.; DALL'ORTO, F.A.C.; OJIMA, M.; MARTINS, F. P. Propagação vegetativa do Umezeiro (Prunus mume) por meio de estacas herbáceas. Revista Brasileira de Fruticultura, v. 21, n.2, ago., p.226-228, 1999.

NAGESWARA RAO, B. B.; SATYANARAYAMA, G.; SHIV RAJ, A.; GNANA KUMARJ, N.; PADMANABHAM, N. Influence of post-ringing period on cofator activity and total phenol content in ringed shoot cuttings of cashew (Anacardium ocidentale L.). Tropical Agriculture. v. 65, n. 4, p. 370-372, 1988. 
NAKASONE, H. Y; PAULL, R. E. Tropical fruits. Crop Production Science in Horticulture Series, CAB International:London, 1998. $445 \mathrm{p}$.

NICOLOSO, F. T.; LAZZARI, M.; FORTUNATO, R. P. Propagação vegetativa de Platanus acerifolia Ait: (II) Efeito da aplicação de zinco, boro e ácido indolbutírico no enraizamento de estacas. Ciência Rural, v. 29, n. 3, p. 487-492, 1999.

NORMANLY, J. Auxin metabolism. Physiologia Plantarum, n.100, p. 431-442, 1997.

OLIVEIRA, A.F. Enraizamento de estacas semilenhosas e cultura de embriões in vitro de oliveira (Olea europea L.). Lavras, 2001, 122 p. Tese (Doutorado) - Universidade Federal de Lavras.

Organização Mundial do Comércio. (htpp://www.wto.org). (19.jul.2002).

ONO, E. O. Interação entre auxinas e ácido bórico no enraizamento de estacas caulinares de Coffea arabica L. cv "Mundo Novo". Botucatu, 1990. Dissertação (Mestrado) - Universidade Estadual Paulista "Julio de Mesquita Filho".

ONO, E. O., RODRIGUES, J. D. Aspectos da fisiologia do enraizamento de estacas caulinares. Jaboticabal: FUNEP, 1996. 83 p.

OSHIO, H.; KOBAIASHI, M.; NAKAGAWA, S.; SAKURAI, A.; TAHAHASHI, N.; IZUMI, K. Levels of IAA, cytokinins, ABA and ethylene in rice plants as effected by a gibberelin biosynthesis inhibitor, uniconazole-P. Plant Cell Physiology, v.29, n. 1, p. 87200, 1988. 
PANELLI, G.; FILIPUCCI, B.; DADDI, P. Rizogenesi e ciclo vegetativo in Olea europaea L cv. 'Frantoio', 'Leccino' e 'Morailo'. Influenza di trattamenti co fitoreguladori basali e fogliari a diverse concentrazioni. Annalli dell'Istituto Sperimentale per I'Olivicoltura. v.6, p. 135-150, 1980.

PEARSE, H. L. Rooting of vine and plum cuttings as affected by nutrition of the parent plant and treatment with phytohormones. Dept. of Agr. Union of South Africa, 1946.

PEREIRA, F. M.; OIOLI, A. A. P.; BANZATTO, D. A. Enraizamento de diferentes tipos de estacas enfolhadas de goiabeira (Psidium guayava L.) em câmaras de nebulização. Científica. n. 11, v. 2, p. 239-244, 1983.

PEREIRA, M. Ação de reguladores e estimulantes vegetais em cafeeiro (Coffea arabica L.) podados e não podados. Piracicaba. 1992, 58 p. Dissertação (Mestrado) - Escola Superior de Agricultura "Luiz de Queiroz" - Universidade de São Paulo.

PEREIRA, F. M.; PETRECHEN, E. H. de; BENINCASA, M. M. P.; BANZATTO, D. A. Efeito do ácido indolbutírico no enraizamento de estacas herbáceas de goiabeira (Psidium guajava) das cultivares 'Rica' e 'Paluma', em câmara de nebulização. Revista Brasileira de Agrociência, v.1, n. 2, mai.-ago., p.112-114, 1995.

PERES, L. E. P.; KERBAUY, G. B. Controle hormonal do desenvolvimento das raízes. Universa, n.8, p.181-195, 2000. PIATKOWSKI, M. G.; JANKIEWICZ, L. S.; KASPRZYR, S. Use of auxin, fungicides and rooting cofactors to induce adventitious root formation in softwood cutting of apple, gooseberry and some ornamental plants. Acta Agrobotânica. v. 26, n.1, p. 191-201, 1973. 
PINTO, A.J.D.; INFORZATO, R., SANTOS, S.R; ABRAMIDES, E. Efeito da aplicação de hormônios vegetais sobre mudas de citronela. Bragantia, v.67, n.22, p. 807-815, 1963.

PREÇOS AGRÍCOLAS. Piracicaba:ESALQ, n. 165, jul., p.42, 2000.

RALLO L.; del RIO, C.; Effect of a $\mathrm{CO} 2$ enriched environment on the rooting ability and carbohydrate level of olive cuttings. Advances in Horticultural Science, v. 4, n.2, p. 129-130, 1990.

RAVEN, P.H.; EVERT, R.F.; EICHHORN, S.E. Biology of plants. :

New York: Worth Publishers., 1992. 730 p.

REIS, J. M. R. Uso do estiolamento e do ácido indolbutírico no enraizamento de estacas de Pyrus calleryana Dcne. Lavras, 1999, p.2. Dissertação (Mestrado) - Universidade Federal de Lavras.

REZENDE, G. M. de; SOUZA, R.J.de; SAGGIN JUNIOR., O.J.; FLORI, J.E. Produtividade e qualidade de bulbos de alho em diferentes doses de paclobutrazol e períodos de frigorificação. Ciência e Agrotecnologia, v.25, n.6, nov./dez., p.1343-1350, 2001.

ROBINSON, J. C.; SCHWABE, W.W. Studies on regeneration of apple cultivars from root cuttings. Carbohydrate and auxin relations. Journal of Horticultural Science, n. 52, p. 221-233, 1977.

RODRIGUES, J. E. L. F.; LUCCHESI, A. A. Propagação Vegetativa do guaranazeiro (Paullinia cupana (Mart.) Ducke) através de estacas induzidas (capeadas) e com ácido indolbutírico. Anais da ESALQ, v.44, p. 1-20, 1987.

RODRIGUES, J. D., ONO, E. O., FOLONI, L. L. Efeito da aplicação de uniconazole na cultura de soja (Glycine max (L.) Merrill CV IAC-17). Scientia Agrícola, v.55, n.2, p.313-319, 1998. 
ROSSAL, P. A. L.; KERSTEN, E. Efeito do ácido indolbutírico no enraizamento de estacas de laranjeira cv. Valência (Citrus sinensis (L.) Osbeck) sob condições intermitentes de nebulização. Scientia Agricola, v. 54, n. 1/2, Jan/ago, p. 9-13, 1997.

RUBBO, M. S.; GASPARETTI, L. A. Fruteiras silvestres e exóticas. Informativo SBF, v. 4, n. 3, p. 18-19, 1985.

RYAN, G.F. Etiolation as na aid in propagation. Proceedings American Society Horticultural Science, v.19, p. 69-74, 1969. SAlisBURY, F. B.; ROSS, F. B. Plant Physiology. 2 ed., Belmont: Wadsworth, 1978. 422 p.

SAMPAIO, V. R.; BARBIN, D. Propagação de pereira através de estacas folhosas em ambiente de nebulização. Anais da ESALQ, v. 40, n. 3, p. 509-517, 1983.

SAMPAIO, V. R. Enraizamento de estacas de laranja Pêra (Citrus sinensis Osbeck). In: CONGRESSO BRASILEIRO DE FRUTICULTURA, 10., Fortaleza, 1989. Anais. Fortaleza: Sociedade Brasileira de Fruticultura, 1989, v.1, p. 22-23.

SANTOS, M. H. dos. Estudo químico dos frutos de Rheedia gardneriana (PL. e TR.) e aplicações biológicas dos seus constituintes. Viçosa, 1996. 114 p. Dissertação (Mestrado) Universidade Federal de Viçosa.

SARMENTO, B.M.M. de; POMMER, C.V.; VEIGA, R.F.A de; SOARES, N.B. Efeito de doses de ácido naftalenoacético sobre o enraizamento de três cultivares de kiwi (Actinidia deliciosa), com o uso de NAA. Arquivo pessoal do autor, 1999. 
SCARPARE FILHO, J. A.; TESSARIOLI NETO, J.; COSTA JÚNIOR, W. H.; KLUGE, R. A. Efeito do ácido indolbutírico no enraizamento de estacas herbáceas de jaboticabeira "Sabará" (Myrciaria jaboticaba) em condições de nebulização. Revista Brasileira Fruticultura. v. 21, n. 2, ago., p. 146-149, 1999.

SCARPARE FILHO, J. A.; ALMEIDA, W.A.B. de Multiplicação de plantas: reprodução e propagação. Revista Universa: Ciências Biológicas, da Saúde e Médicas, v.1, p.67-80, 2002.

SHAW, P.E.; CHAN, H.T. JUNIOR.; NAGY, S. Tropical and subtropical fruits. AGSCIENCE:Flórida, 1998. 569 p.

SECEX/MDIC - Secretaria de Comércio Exterior/Ministério do Desenvolvimento, Indústria e Comércio. (http://www.mdic.gov.br). (20.jul.2002).

SILVA, I. C. Propagação Vegetativa-Aspectos Morfológicos. Belém-Pará: Depto Especial da Amazônia, Bol. Téc. 4, 1994. (Bol. Tec., 4).

SIMÃO, S. Manual de Fruticultura. São Paulo: Ceres, 1971.530 p. SINGH, S. N.; TAOTIA, S. S. Effect of some hormones on rootage of mango. Science and Culture, v. 17, p. 207-210, 1961.

SINGH, M. Effect of zinc, phosphorus and nitrogen on tryptophan concentration in rice grains grown on limed and unlimed soils. Plant and Soil, v. 62, n. 2, p. 305-308, 1981.

STENLID, G. Cytokinins as inhibitors of root growth. Physiologia Plantarum, n.56, p.500-506, 1982.

STRUCKMEYER, E. S. Comparative effects of growth substances. Madison: Wisconsin, p. 167-174, 1951. 
STUMPF, E. R. T.; GROLLI, P. R.; SILVA, J. A. G. da Enraizamento de estacas de Chamaecyparis lawsoniana Parl. em cinco substratos com uso de ácido indolbutírico. Ciência Rural, v. 29, n. 2, p. 207$211,1999$.

SYKES, J. T.; WILLIAMS, I. H. Factors affecting regeneration from cuttings using mist technique. Annual Application Biology, v. 47, n.3, p. 613-614, 1959.

TERRA, M. M. Nutrição e adubação da videira. In: SIMPÓSIO BRASILEIRO SOBRE UVAS DE MESA. Ilha Solteira, 2000. Anais. Ilha Solteira: Ed., 2001. 328 p.

THIMBA, D.N.; ITULYA, F.M. Rooting of purple passion fruit (Passiflora edulis forma edulis Sims) stem cuttings. II. Influence of indolbutírico acid (IBA). East African Agricultural and Forestry Journal, v. 1, n. 48, p. 5-9, 1982.

TOCCHINI, R. P.; NISIDA, A. L. A. C.; MARTIN, Z. J. Industrialização de polpas, sucos e nectares de frutas. ITAL, Campinas:ITAL, 1985, p. 18-19. (Manual Técnico).

TREWAVAS, A. How do plant growth substances work? Plant Cell and Environment, n.4, p. 203-228, 1981.

VEIGA, R. A. Banco ativo de germoplasma de espécies nativas mantido no Instituto Agronômico. In: SIMPÓSIO LATINO AMERICANO DE RECURSOS GENÉTICOS VEGETAIS, I., Campinas, 1997, Anais. 1997, p. 64.

VERDONCK, O.; VLEESCHAUWER, D.; DE BOODT, M. The influence of the substrate to plant growth. Acta Horticulturae, v. 126, p. 251-258, 1981. 
VIEITZ, A.M.; BALLESTER, A.; GARCIA, M.T.; VIEITZ, E. Starch depletion and anatomical changes during the rooting of Castanea sativa Mill, cuttings. Scientia Horticulturae, v. 13, p.261-266, 1980.

VILANOVA, M. T. Propagación vegetativa del café. Café Salvador, n. 29, 1959, p. 669-681.

VLACHOV, D.D. Vegetative propagation of $\mathrm{sp.} \mathrm{Platanus} L$. through rooting of cuttings. Acta Horticulturae, v.226, p. 375-378, 1988. VOLPE, C. A. Fenologia dos citros. In: SEMINÁRIO INTERNACIONAL DE CITROS, FISIOLOGIA, 2., Campinas, 1992. Anais, Campinas: Cargill, 1992, p. 107-119.

WEAVER, R. J. Reguladores del crescimento de las plantas en la agricultura. Editorial Trilhas México, 1976. $621 \mathrm{p}$.

WEAVER, R. J. Reguladores del crecimiento en la Agricultura. Barcelona: Trillas, 1982, 540 p.

WEISER, C. J.; BLANEY, L. T. The nature of boron stimulation to root initiation and development in beans. Ibid, v. 90, p. 191-200, 1967.

WILLIAMS, R. R.; TAJI, A. M.; BOLTON, J. A. Suberization and adventitious rooting in Australian Plants. Australian Journal Botanic, v. 32, p. 363-366, 1984.

WINKLER, A.J.; COOK, J.A.; KLIEWER, W.M.; LIKDER, L.A. General viticulture. Berkeley:University of California, 1974. $710 \mathrm{p}$.

WRIGHT, R.C.M. The complete handbook of plant propagation. New York: McMillan, 1975.191 p. 
ZUFFELLATO-RIBAS, K. C.; OLIVEIRA, F. W.; CARPANEZZI, A. A.; TAVARES, F. R. Interações entre a época do ano e a aplicação de IBA e ácido bórico no enraizamento de estacas de Ficus enormis In: CONGRESSO NACIONAL DE BOTÂNICA, 51., Brasília, 2000, Resumos. Brasília: Universidade de Brasília, 2000 , p.44. 